\title{
Tropicality and the Choc en Retour of Covid-19 and Climate Change
}

\author{
Daniel Clayton \\ https://orcid.org/0000-0003-2557-5495 \\ University of St Andrews, Scotland
}

\begin{abstract}
This article reads 'pandemic, plague, pestilence and the tropics' through Covid-19, climate change and the discourse of tropicality. It asks: What happens, as seems to be the case today, when the temperate/tropical oppositions around which tropicality revolves start to unravel because the aberrations and excesses (here of epidemic disease and extreme weather) hitherto deemed to belong to tropical areas, and as constitutive of their otherness, are found in temperate ones? This question is broached with a focus on the United Kingdom as one such 'temperate' place that currently finds itself in this situation (although the argument has broader resonance), and with Aimé Césaire's ideas about the choc en retour (boomerang effect) of Western colonisation and la quotidienneté des barbaries (the daily barbarisms) by which this effect works. Evidence and feelers from science, theory, politics, and the media are used to consider how sensibilities of tropicality, and especially (as Césaire enquired) distinctions between the 'normal' and 'pathological,' and 'immunity' and 'susceptibility,' permeate the way Covid-19 and climate change are perceived and felt in the temperate world.
\end{abstract}

Keywords: Covid-19, climate change, choc en retour, tropicality, Aimé Césaire 
eTropic 20.1 (2021) Special Issue: Pandemic, Plague, Pestilence and the Tropics

And then one fine day the bourgeoisie is awakened by a terrific boomerang effect [choc en retour]: the gestapos are busy, the prisons fill up, the torturers around the racks invent, refine, discuss.

People are surprised, they become indignant. They say: "How strange! But never mind - it's Nazism, it will pass!" And they wait, and they hope; and they hide the truth from themselves, that it is barbarism, the supreme barbarism, the crowning barbarism that sums up all the daily barbarisms [la quotidienneté des barbaries].

- Aimé Césaire, Discourse on Colonialism, 2000, p.36

\section{'And then one fine day...'}

he theme of "pandemic, plague, pestilence and the tropics" is read here through Covid-19, climate change and the idea of tropicality. Tropicality is the age-old discourse (or suite of ideas, experiences, sensations and representations) through which 'the West' regards itself as 'temperate' (moderate, secure, comfortable, self-controlled and staid) and 'the tropics' as alien and its opposite (a domain of allure, seduction, danger, riot and excess). This temperate/tropical opposition has been conceived foremost in environmental terms, historically through capitalist and colonialist expansion and exploitation, and with factors of climate and disease, and health and hygiene, paramount. Tropicality helped to produce empire and buttress Western ideas of dominance and superiority. But it has outlived the age of European colonial empires and continues to shape and split 'global' understanding and experience (see, e.g., Allewaert, 2013; Arnold, 2005; Bowd \& Clayton, 2019; Driver, 2004; Stepan, 2001; Sutter, 2014).

This article has three aims and four main sections. The first (general and twofold) aim is to consider how the idea of tropicality facilitates understanding of Covid-19 and climate change, and how these two global calamities impinge on how tropicality works today. The second aim is to alight on one of the key upshots of Covid-19 and climate change in relation to tropicality: the ways in which they expose and fracture how questions of climate and disease are seen through temperate/tropical oppositions. More specifically, I ask: What happens when elements of 'the tropical' are found in 'the temperate' - that is, when some of the locational and perceptual markers associated with tropicality are twisted and inverted? Is tropicality thereby unravelled? The third 
eTropic 20.1 (2021) Special Issue: Pandemic, Plague, Pestilence and the Tropics

aim is to underscore the pertinence of Aimé Césaire's mid twentieth-century critique of the choc en retour (boomerang effect) of Western colonisation on human and planetary dynamics to the above questions and concerns.

These three aims are threaded through an argument that is developed over four sections and shuttles between theory and example, and problem and place. I shall start by putting the terms in my title further into play, and do so by pointing to the significance of questions of immunity - exception, exposure, protection and susceptibility - to how tropicality, Covid-19 and climate change might be connected. Césaire's boomerang effect is introduced at this point as a means of broaching these connections and of bringing my second aim into focus.

The article then visits the United Kingdom (UK), which is seen as one such 'temperate' place that is currently plagued by 'tropical' exigencies (although I think the issues arising from this example are of broader resonance). This conjuncture is spotted and pursued through the "Plague Island" epithet that the New York Times (NYT) bestowed on the UK in December 2020, chiefly to castigate the government's handling of the pandemic. A wider and deeper discussion of Césaire's choc en retour, and his linked formulation about la quotidienneté des barbaries (daily barbarisms), then follows, with this disquisition used to tease out links between Covid-19 and climate change and reflect further on how tropicality today involves relations and forces of circulation as well as ones of opposition. Finally, the article returns to the UK, there to probe how Covid-19 and climate change both expose and breach the country's 'temperate' identity. The conclusion takes stock of the findings and contribution of the article and thinks a little further about how the above travails of tropicality might be hooked up to wider concerns about 'inside' and 'outside' distinctions and geographies of difference, indemnity, power and violence.

\section{Politics, Putrescence and the Weather}

The discourse of tropicality centres on how 'the tropics' have been constructed viewed, encountered, invented, coveted, and controlled - by Western travellers, scientists, settlers, soldiers and traders as they explored and moved into tropical regions and derived a set of 'temperate' values and 'tropical' vistas from their experiences. It is chiefly a product of modern empire-building, although Western writing about the 'torrid zone' stretches back to Ancient times (see Cosgrove, 2005). Akin to the way Edward Said (1978, pp. 55-73), in his celebrated study Orientalism, construes 'the Orient' as an "imaginative geography", David Arnold (1995, pp. 141$142 ; 1998$, p. 4) argues that "'the tropics' need to be understood as a conceptual, and not just physical, space", and with the tropics potently, if spuriously, spatialised qua the "perceived normality of the northern temperate zone". 
eTropic 20.1 (2021) Special Issue: Pandemic, Plague, Pestilence and the Tropics

Tropicality has an overtly environmental hue and has been discharged in both positive and negative terms, with the tropics seen and experienced in some times and places as 'paradisical' and in others as 'pestilential' (Arnold, 2005). This discourse has linked metropole and colony, and settler and native, through a range of projects and practices: science and medicine, art and architecture, war and slavery, travel and tourism, and plantation trade and resource extraction. Colonialism in the tropics was always an alluring yet challenging prospect: a route to material and personal enrichment, but also a snare of disappointment, presenting the 'temperate/northern' self with immense difficulties, and with "climatically-determined differences between human 'races' and cultures...central to Western European self-conceptions of an inherent superiority over [non-Western and tropical] people" (Mahoney \& Endfield, 2018, p.2). Colonial 'success' was more readily associated with Europe's 'temperate' colonies (Acemoglu \& Robinson, 2019). As Harish Naraindas (1996) argues in one of the first (and still richest) essays on tropicality, in tropical colonies, where climate and disease were kings, there were close and unsettling connections between "poisons [by which he also means politics and power], putrescence and the weather."

To use Said's and Jacques Derrida's terms (and thus acknowledge their theoretical influence over writing on tropicality), the temperate is a "priority" - and deemed "normal, pure, standard, self-identical" (Derrida, 1977, p. 93) - over the 'tropical', and the latter serves as the former's "surrogate and even underground self" (Said, 1978, p. 3). My concern here is with how Covid-19 and climate change variously expose, disguise, and subvert this hierarchical ordering of temperate and tropical and the 'priority' it arrogates to the temperate. Considerable attention has been paid to how tropicality nestles into and shapes the tropics, and how Western understanding and experience dominate and distort - that is, to how temperate actors and entities move into and control the tropics. The question of what happens within the temperate 'home' of tropicality, and especially if or when its precedence is threatened, has received less attention and is my quarry here. What happens if or when the tropical winds up in the temperate? It is suggested that the UK is one such temperate place whose 'priority' is currently being put in jeopardy by Covid-19 and climate change.

Tropical incursion into the temperate has always been a facet of tropicality, and most conspicuously through practices and processes of anti-colonialism, post-colonial migration, cultural hybridity and multiculturalism (see Stam, 1997). Yet such inroads have been localised and prone to being co-opted into tropicality's uber architecture of the ordinary and the exotic. Things are arguably different with Covid-19 and climate change. These eventualities have more pervasive effects and threaten the whole architecture of tropicality en bloc. The UK is by no means the only temperate place that finds itself in a troublesome situation in this regard - with what (and through a long 
eTropic 20.1 (2021) Special Issue: Pandemic, Plague, Pestilence and the Tropics

colonial history of tropicalising) it has made of the tropics - and its difficulties are specific. But its experience is instructive. What this trouble involves - an embattled exoticism as well as intensification of extreme weather (heatwaves, droughts, storms, floods and wildfires) and emergence of new diseases - is becoming an increasingly 'normal' part of life in temperate parts of the world.

There is a danger here, of course, that such an orientation might do what was done to anti-colonial incursions (a counter-tropicality) before: the dispersion and subversion of tropical meaning 'in and for the tropics' might end up getting re-captured within a temperate/Western horizon of signification. Indeed, parts of the tropical world (Brazil and Indonesia, for example) have been hit hard by Covid-19 and at the start of the pandemic there was an air of temperate superiority (both complacency and deprecation) about how the pandemic might unfold. It was prophesied that while things might get bad for Western countries, they could well end up much worse for developing/tropical countries, due to "their overburdened public health systems, dearth of testing facilities and overcrowded slums" (Winning, 2020). But this, of course, has not been borne out by data, and partly because many of these putatively 'vulnerable' countries (Nigeria, Sierra Leone, Zimbabwe, for example) are more closely acquainted with epidemic diseases (Ebola and HIV recently, for instance) and able to deal with them effectively at a local level (Nguyen et. al., 2021). In fact, as Tony Blair's Institute for Global Change (2020) reports, "Early on, Covid-19 was perceived by many in the Global South as a 'disease of the rich' - concentrated in well-off neighbourhoods and expat compounds, brought into the region by business travellers and the mobile elite".

This inversion of meaning and expectation is revealing and informs much of what follows. I shall sally into this terrain with evidence and feelers from science, theory, politics and the media. I shall also do so by returning to the Martinican writer and politician Aimé Césaire's incisive indictment of the boomerang effect (choc en retour) of centuries of colonisation on "la civilisation malade" (the bilious and dying culture) of the imperial West in his 1950 Discours sur le colonialisme (1955, p. 13, 18; 2000, p. 36). Césaire, himself, was no stranger to the idea of tropicality. In fact, it is not generally recognised that from the 1940s onwards he deployed the term tropicalité to convey something similar in an anti-colonial vein (1955, p. 43; Césaire \& Roussi, 1978; see Bowd \& Clayton, 2019). Césaire saw 'the tropics' as a scene par excellence not only of colonial rapacity but also of how the violence embedded in a host of oppositions - between the usual and strange, normal and pathological, moderate and excessive, refined and gaudy, hallowed and plagued, immune and susceptible, hospitable and inhospitable, resplendent and insipid, and vigorous and languid - had been disguised and deflected. 
eTropic 20.1 (2021) Special Issue: Pandemic, Plague, Pestilence and the Tropics

The issue of how extreme, anomalous and deleterious relations and sentiments are placed 'outside' normality and acceptability, yet are constitutive of their 'inner' sanctity and reality, lies at the heart of his idea of the boomerang effect, and he coined the term la quotidienneté des barbaries (daily and banal barbarisms) to think about how 'outside' and 'inside' are connected and the violence that this opposition effects. In the present context, I explore how, in the UK (although, again, a wider view might be glimpsed from there), Covid-19 and climate change have been imagined as extraneous to, and yet as impacting deleteriously upon, temperate regions - as outside the 'normality' of temperate experience (or at least recent experience), as exotic and excessive (in the parlance of tropicality), and yet now part of its make-up.

Césaire's work flags issues that are given relatively small space in the literature on tropicality, and are also underplayed in those on climate change and Covid-19: What happens to the 'normality' of the colonising/temperate/northern zone when its holding patterns of projection and exoticism - the means by which tropical otherness is installed and kept in place - are threatened and ruptured and the violence of this undertaking, which has always been latent on the inside, is exposed? What happens when tropicality spills out of its temperate containers and packaging, in medical laboratories, museums and exhibitions, travel products and tourist destinations, supermarket shelves, and so on, and becomes more wildly contagious and unpredictable (i.e. when the packaging comes off and the containers leak)?

We shall see that Césaire's choc en retour involves ideas of both shock and vigilance. Distant problems and power relations come home to roost in both startling and foreseeable ways, he argued, and the whole process of projection and pingback needs to be watched carefully. He was concerned, in part, with how a colonial/tropical outside and otherness that is made by the norms of a temperate/imperial inside can nonetheless subvert this making and thereby point to the possibility of a different way of knowing, or counter-tropicality (to which I shall return). But he also turned to the inside of la civilisation malade, and especially to how it disavows and limits the means by which the outside 'gets in', and how this restriction (to adopt current Covid lingo) becomes part of that inside's lockdown (i.e. a symptom of its malaise).

These concerns also come with the undertow of Achille Mbembe's (2020a) declaration of a "universal right to breathe". "It is one thing to worry about the death of others in a distant land", he writes,

and quite another to suddenly become aware of one's own putrescence, to be forced to live intimately with one's own death, contemplating it as a real possibility. Such is, for many, the terror triggered by confinement: having to finally answer for one's own life, 
eTropic 20.1 (2021) Special Issue: Pandemic, Plague, Pestilence and the Tropics

to one's own name. We must answer here and now for our life on Earth with others (including viruses) and our shared fate.

He refers not just to Covid-19, which kills by taking the breath away, but also to a "pathogenic...[and] catabolic period par excellence, with the decomposition of bodies, the sorting and expulsion of all sorts of human waste" and into which climate, capital, disease, environment, race, and the extra judicial powers of corporations and the state (currently the coronavirus state) all feed, spawning "the damage we as humans wreak on the lungs of the earth and on its body" (2020a). My suggestion is that the choc en retour of Covid-19 and climate change, in the UK for example, resides in relations of isolation and interdependence that lay bare, fracture and flip this 'sorting'.

Isolation hinges on the 'great confinement' and 'frozen space' of lockdown (to extend Michel Foucault's well-known adages concerning the advent of a disciplinary regime of power and its panoptic spaces of the prison, clinic, factory and school). Current 'scourges' of climate change, and especially Covid-19, jolt liberal ideals of free and innocent social and global mobility, interaction and consumption. Foucault's (1978, p. 181) idea of the bio-political "threshold of modernity" - of "bringing to life or rejecting in death" - revolves around the bodies of individuals and fortunes of populations: on the calibration and monitoring of their birth, health, consumption habits, accidents, old age, and passing; and on a plague mentality that regulates by partitioning and quarantining. "The following, according to an order published at the end of the seventeenth century", Foucault (1977, p. 195) famously observed with respect to this mentality, "were the measures to be taken when the plague appeared in a town":

First, a strict spatial partitioning: the closing of the town and its outlying districts, a prohibition to leave the town on pain of death, the killing of all stray animals; the division of the town into distinct quarters, each governed by an intendant.... It is a segmented, immobile, frozen space. Each individual is fixed in his place. And, if he moves, he does so at the risk of his life, contagion or punishment.

2020 was the year in which the plague mentality upon which modern bio-politics were built was hastened back to life. In the case of Covid-19, this involved a combination of lockdowns (a term hailing from the American prison system), and what (felicitously, although in some ways misleadingly) has been called "social distancing" (a term from 1970s American sociology that began to jump from there into public heath discourse with the SARS epidemic of 2003 - see Drum, 2020). These practices of confinement and partitioning are also in keeping with (although not exclusive to) the populist isolationist - repose of the political times, and with countries around the world forging their own resolutely national responses to Covid-19. 
eTropic 20.1 (2021) Special Issue: Pandemic, Plague, Pestilence and the Tropics

But Covid-19, and climate change, are also, and obviously, about interdependence, and in a fourfold sense. First, in terms of fomenting urgent questions (à la Mbembe) about what 'we' owe to each other, and how we care for one another in partisan times. Second, by virtue of the perhaps unprecedented scientific collaboration that has gone into the rapid creation of effective vaccines. Third, and as Andrew Liu (2020) observes, the origins and range of both of these global calamities can be found in interlocking processes of rampant commodification, habitat destruction, fossil fuel extraction, animal trafficking, and "mundane routines" of international business, education, trade, and tourism, all of which bear "the footprint of the marketplace". Fourth, and as Glen MacDonald (2020) notes, both also raise fundamentally geographical questions of privilege and perspective: of where climate change and zoonotic diseases are hitting hardest, and who are best placed to bear their brunt. We also need to be mindful, he says, of the skewed recognition that Covid-19 is regarded as a 'world' problem because it has a particularly dire trajectory within 'the West'. He reminds us that there are diseases other than Covid-19, many of them 'neglected' tropical diseases, that kill and incapacitate many more of 'the rest' on a yearly basis (Chagas Disease, Dengue fever, malaria, Trachoma, for example). They may become even more neglected as medical laboratories and vaccine producers steer their energies and finances towards this new coronavirus, although some suggest that Covid-19 augurs a step-change in scientific and medical understanding of viruses, and one that has been built, in part, on research into HIV and Ebola (Ntoumi, 2020).

Nevertheless, and to round off this section: What happens when tropicality's geographically pinpointed semantics of disease (contagion and pestilence) and climatic surfeit (extreme weather and bodily duress) become globally life-threatening forces and constitute a 'new normal', which is how they are increasingly represented, including by the World Health Organization (2020)? The expression 'new normal' first started to be used in connection with the 'bird flu' of 2003-05 and financial crisis of 2007-08, and I use it here in an extended sense, to denote a new universal (in Mbembe's sense) that threatens to exceed its over-determination by 'other' problems and afflictions that originate and reside 'elsewhere.' "There's nothing new about the 'new normal'", Chime Asonye (2020) avows in a recent World Economic Forum blog, and it "must not be the lens through which we examine our changed world" because "'normal' has not worked for a majority of the world's population." And tropicality is pivotal to the story of how and why 'normal' has not worked.

\section{Hello from 'Plague Island'}

I now seek to contextualise and exemplify these conceptual concerns by stepping into "Plague Island", which is how the NYT stigmatised the UK on 21 December 2020 
eTropic 20.1 (2021) Special Issue: Pandemic, Plague, Pestilence and the Tropics

following the identification in southern England of a mutant, and more virulent and deadly, 'Kent variant' of Covid-19, and the hasty re-introduction of lockdown measures, and with many countries (including the United States) closing its borders to UK travellers (Henley, 2020). Previously, in the weeks leading up to the first (March 2020) lockdown, civil servants had dubbed Westminster (the heart of government) a "plague pit"; everyone, including the Prime Minster, Boris Johnson, seemed to have caught coronavirus (Elgot, 2021).

Then, on 24 December 2020, the UK Government signed a 'free trade' deal with the European Union, ending four rancorous years of 'Brexit', and with a profoundly ironic denouement: the fulfilment of Britain's quest (at least on the part of the ideologically fixated or duped 'Brexit' parts of it) to restore its "national sovereignty" and once again become a "free, buccaneering, global trading nation" (as the Tory press had it), came at the precise moment that borders were being closed. 3000 trucks got stranded at the UK's southern ports, and drivers were "treated like animals", with little access to toilet facilities and water (Mirror, 2020; Saunders, 2019).

Brexit was tinted, to be sure, by imperial nostalgia, xenophobia, and a little Englandisland mentality. "The one good thing to come out of Brexit", leading scholar of contemporary British history, David Edgerton (2020) quipped sardonically, is "a bonfire of national illusions". One of these illusions was about the country's trading prowess. Among other things, Brexit pointed to an inferno of tropical exploitation and sweatshop and plantation geographies, global supply chains (of cheap clothes and staples of sugar, coffee, tea, cotton, timber, and so on), and opaque yet brutal circuits of financialised and racialised capital linking Luanda and Koh Kong to Leicester and Coventry (Cole, 2020; Kumar, 2020; Ratcliffe, 2021; Ross, 2017). Meanwhile, unable to gallivant in search of new trade deals (and plantations and cheap workers), the only thing saving the UK from being completely derided from afar for the way its bungling government had dealt with the virus was empathy for those who have lost loved ones to the disease.

In March 2020 the UK Government invoked 'emergency powers' to impose a national lockdown, ordering people to "stay home" in order to "save lives" and "protect the NHS" (the UK's National Health Service) (UK Gov, 2020a). Other countries did the same, and civil liberties groups were quick to point to unprecedented restrictions on individual liberty (Greene, 2020). Across Europe, but especially in the UK (and also in the US), Covid-19 also exposed chronic underfunding in public health provision, the privatisation of health systems (research and hospital facilities, and equipment supply chains), and, concomitantly, "the systemic weakness of neo-liberalism" as a public service project (Mellish et. al., 2020). The hospital bed base of the UK is two-thirds smaller than that of Germany. 
eTropic 20.1 (2021) Special Issue: Pandemic, Plague, Pestilence and the Tropics

The impact of Covid-19 on the UK was compounded by 'extreme' weather and 'abnormal' seasonal temperatures, and the Government was found wanting in this regard as well, with 'too little too late' investment in flood protection, sea defences, river management, land use and emergency planning, and with an ambiguous mix of mitigation and adaptation policies (CCC-ASC, 2010). At the end of 2020 - the most 'extraordinary' year in the country's history since World War II, its people were told by their Queen and Prime Minister - news bulletins were replete with harrowing footage of ambulances struggling through flooded city streets and country lanes to get Covid19 patients to hospitals that were fast running out of beds. In short, the UK was hit by a double whammy of meteorological misfortune and public health calamity, and these were events not 'normally' associated with these 'fair isles' (McCarthy, 2021). More generally, in the spring of 2020, and again at the end of the year, there were British, European and American news headlines about "tsunamis" of Covid-19 patients "flooding" hospitals (e.g. Bodkin, 2020; Lee, 2020; Mason, 2020). Tropical storm Chalane "hitting" Mozambique, and the "tsunami" of Covid-patients "threatening hospitals" around the world, were explicitly linked in the January issue of Reuters' (2021) Natural Disasters blog.

Tropicality does not give a full or immediate measure of this. A political rhetoric of reaction regarding liberty quickly flared, and with Europe's leading philosophers (Giorgio Agamben, Roberto Esposito, Julia Kristeva, Jean-Luc Nancy, and Slavoj Žižek, for example) wading in (see e.g. Delanty 2020). They asked about whether Covid-19 would be less easily arrested in nations that espouse 'democratic freedoms' than in ones with an 'authoritarian' hue: whether public health measures and restrictions on personal liberties would be harder to implement and maintain, and 'lockdown fatigue' would arise more quickly, in the former than in the latter (e.g. Agamben, 2020). That is, they asked about whether the virus tells us anything new about freedom and democracy.

Furthermore, correlations between the course and severity of Covid-19 around the world, and the relative stringency of restrictions and public adherence to them, do not yield firm conclusions. Viewing matters from Italy, Simone Redaelli (2020) relays the maxim that 'freedom' is a contingent and contested, and elastic and embattled, idea and practice. "The Covid-19 era", he adds, "is a historic moment in which, according to how democracy is formulated, the sole freedom allowed [at least in the Italian Constitution] is the one 'to survive', is the one 'to biologically persist'." The global map is complex. Mark Peters (2020) notes that there have been different national responses to the virus, for instance, within nominally similar "authoritarian capitalist" (e.g. Brazil, China, Singapore) and "empathetic socialist" (e.g. New Zealand, Sweden, Vietnam) political set-ups (also see Howell, 2021). Considerable caution should also 
eTropic 20.1 (2021) Special Issue: Pandemic, Plague, Pestilence and the Tropics

be exercised with regard to the conclusion to which some began to jump, 'as the data came in', about climate and temperature being key variables in the impact of Covid19 , and about the virus having distinct trajectories in 'temperate' and 'tropical' countries and being three (and possibly six) times more deadly in the former than in the latter (e.g. Chen et. al., 2020; Hasan \& Haque, 2020; Tushabe, 2020). The British Medical Association (2020) issued a more general warning that "the COVID-19 pandemic has created a flood of potentially substandard research", and not just in the medical realm.

All of this matters. Yet the language of storms and tsunamis is not innocent. "The exhaustion - and perhaps the sadness - of Britons saying goodbye to 2020", Brigid Delaney mused, "comes from saying goodbye to our old life" (2020). The counsel to be found in this and much other journalism and social media is that 'old' connotes routine and stable, and in ways that things like tsunamis palpably do not. While tsunamis are of course generated in all the world's oceans and seas, they occur with most frequency and greatest intensity in the tropical and sub-tropical littorals of the Pacific and Indian Oceans (from Japan to Indonesia and Chile). The term is mobilised as an exoticising metaphor in the UK Covid-context for a new and unparalleled peril that the country did not expect and for which it was woefully unprepared. By contrast, Sujata Morti (2015, p. 167) shows how, in India and other tropical countries, television news coverage and public perception of extreme weather and its impacts (floods, droughts, landslides and cyclones) is shaped both by a discrete cultural politics (in India's case, a gendered Hindu nationalism) and a longer colonial history and language of technological know-how that is rooted in tropicality. The latter happens mainly through the idea that such extremes "belong" to the environment rather than government (colonial or post-colonial) policy, she argues, and that the state is there to "tame" and "conquer" them. While India is one of the 10 countries in the world most affected by extreme weather events, Morti notes that the "horrors" of such occurrences are reported in mundane terms and continue to be deemed part and parcel of India's tropical otherness (2015, p. 168).

A plague island, perhaps, in these ways, the UK is. As ever, words matter - and matter because they are not just words. While scornful, the NYT's epithet for the UK is also sonorous. It carries a range of allusions and begs questions about origins and whereabouts.

As intimated, one obvious allusion is to tropical environments and regions that have been defined by pestilence and excess, and have served as vital 'live' laboratories of medical and scientific research and testing (and with some experiments going far beyond the ethical pale) in the West's imperial quest to conquer disease scourges (Tilley, 2016). Another is to diseases of yore (from bubonic plague and smallpox, and 
eTropic 20.1 (2021) Special Issue: Pandemic, Plague, Pestilence and the Tropics

cholera and tuberculosis, to the Spanish flu of 1918) that have been closer to Western experience and were part and parcel of medieval and early modern European life (Snowden, 2019). The latter demonstrate that the history of epidemic disease is not dominated by the theme of tropicality.

Daniel Defoe's harrowing quasi-fictional account of the visitation of the Black Death upon London in 1665-66, which killed around a quarter of the city's population, in his 1722 A Journal of the Plague Year has stolen the limelight in the UK's Covid-year, just as Albert Camus's 1947 novel La Peste, set in colonial Algeria and serving as a metaphor for the Holocaust, has in France. Both have done so mainly for their verisimilitude. "This was a very terrible and melancholy thing to see, and, as it was, a sight which I cou'd not but look on from morning to night; for there was nothing else of moment to be seen", Defoe (1772, pp. 11-13) wrote, with frightening familiarity for today. "The face of London..., I say, was much altered; sorrow and sadness sat upon every face." A locked down readership formed a macabre attraction to these and other works of Western plague and catastrophe literature, from Shelley's The Last Man to Atwood's MaddAddam trilogy. And having been rejected by publishers in 2005 for being too far-fetched, Scottish crime writer Peter May's thriller Lockdown, with his sleuth investigating how a pharmaceutical giant unleashed an influenza pandemic on London in order to vanquish it with its own vaccine, was rushed into print in April 2020 with the missive that reality is stranger than fiction, and fuelling conspiracy theories about UK scientists and politicians being in lock-step over the pursuit of 'herd immunity' against Covid-19 (which would have involved, by their own admission, a projected 250,000+ UK deaths), and Donald Trump's no less baleful racialisation of Covid-19 as "the Chinese virus" (see Liu, 2020).

An implication of Delaney's piece, and many others like it, however, is that this 'exhaustion' and 'end' of times came from outside normal experience and routine planning. While 'plague' is by no means coterminous with 'the tropics', this experience of being ill-equipped and unprotected chimes with the history of tropicality and is worthy of investigation.

It chimes, in one powerful sense, with the post-Enlightenment romantic-aesthetic encounter with the tropics and Western wonder at the sublime majesty of nature (Driver, 2004; Bowd \& Clayton, 2019, pp. 87-98). But for Césaire, and also from a Caribbean perspective for Fernando Ortiz (1940), this wondrous encounter soon lapsed into an alienating, imprisoning, and ultimately self-defeating impulse to separate culture from nature and keep marvel and majesty on the outside, so to speak. Such misadventure flowed, not least, from the nineteenth-century representation of tropical Africa as 'the white man's grave' (a zone that tested the ill-equipped European body and mind to the point of derangement), and it continues in representations of 
eTropic 20.1 (2021) Special Issue: Pandemic, Plague, Pestilence and the Tropics

Africa as "the infectious continent" (Laino, 2003). "While outbreaks of new, exotic infectious diseases - as well as the resurgence of old killers - have surfaced all over the globe in the past decade", journalist Charlene Laino (2003) observes in a NBC News blog,

no continent has been harder hit than Africa. But with international travellers flying viruses across time zones in a matter of hours, experts have no doubt that the emergence of menacing microbes in one locale could bring about a worldwide pandemic. Are infectious diseases the new Armageddon? Africa's tropical climate makes it a hot zone in the most literal sense. The continent is, to put it simply, a breeding ground for emerging pathogens. Add to that environmental changes - such as global warming and the destruction of the rain forests - rapid population growth and haphazard development, and the scene is set for microbes to thrive, international experts have warned.

In some ways, however, all of this now seems so yesterday. For as some of the above implies, and we shall now see more fully, Covid-19 and climate change are shifting the geopolitics of infectious diseases. A calculus of disease risk and climate peril that until quite recently had been externalised is being pinged back to the West and internalised in jarring ways.

\section{'How strange!' Césaire’s Choc en Retour}

It is easy enough, in general terms, to identify the interlocking choc en retour of climate change and Covid-19 (the tenor of this internalisation). As Dipesh Chakrabarty (2020), for example, summarises (and it is worth quoting him at length):

The pandemic is indeed connected to the period in global history that Earth system scientists and their collaborators have designated 'The Great Acceleration' - c.1950 to now. But it surely caught humanity by surprise, unlike, say, the deadly typhoons, landslides, or firestorms that we have now come to expect from everything we know about the deleterious effects of anthropogenic global warming. Yet, the moment the World Health Organization (WHO) declared COVID-19 to be a pandemic, United Nations (UN) officials in their section on Environment immediately drew a connection between deforestation, destruction of wildlife habitat, growing human affluence, and the pandemic. Some of them even went so far as to describe the pandemic as nature's "warning" to humans. They pointed out-and others have too-that in the last twenty or so years, seventy-five per 
eTropic 20.1 (2021) Special Issue: Pandemic, Plague, Pestilence and the Tropics

cent of the new infectious diseases for humans have been of the zoonotic kind, i.e. they originated when a virus or bacteria jumped species, moving from wild animals to humans. This movement of viruses and bacteria from animal or bird bodies to humans has been hastened by the destruction of wildlife habitat, thanks to the increasing pace of deforestation due to mining, logging, road building, conversion of forests to farmland, expansion of human habitations, illegal trade in wildlife products, and so on.

This boomerang effect is an extension of colonial avarice, Chakrabarty continues, and with environmental disasters induced by colonial policies and latter-day modernisation schemes particularly intense in tropical regions (see Ross, 2017).

There is mounting evidence that habitat destruction, biodiversity loss, deforestation, rampant agricultural commodification, and wildlife trafficking, all of which have been identified as important drivers and expressions of Covid-19 and climate change, are pronounced in the tropical world (e.g. Bloomfield et. al., 2000). Furthermore, Covid restrictions on human mobility, markets and trade are exacerbating food insecurity and fostering opportunistic environmental exploitation in some parts of the tropics.

Synthesising a mass of climate and disease data and modelling, MacDonald (2020, p. 2011) adds that "Anthropogenic climate change will disproportionately affect equatorial regions and closely adjacent areas", which he defines as "the Fateful Ellipse", and with their "vulnerability...exacerbated by a lack of capital for adaptive measures against the impacts of climate change." He avoids the expression "tropical regions' because of its colonial ('white man's grave') connotations, and stresses how, in ensuing decades, "health risks" from a number of "temperate" as well as "tropical" infectious diseases may increase (MacDonald, 2020, p. 2014).

When it comes to the question of whether "our destruction of nature [is] responsible for Covid-19", John Vidal (2020) implores, with clipped circuitry, that we are at the "tip of a fasting-melting iceberg." Western attention to, and condemnation of, the way "deadly diseases new to humans" are "emerging from biodiversity 'hotspots' such as tropical rainforests and bushmeat markets in African and Asian cities" has grown quickly since the start of 2020 (Vidal, 2020; Mouamfon \& Tagne, 2020). In the case of Covid-19, a suspicious finger was soon pointed at Wuhan's 'wet market' (Huanan Wholesale Seafood Market), its sale of the exotic pangolin, native to tropical Asia, and longer and wider trades in "wildlife delicacies" linking mainland China to both adjacent and distant tropical ecosystems (Liu, 2020). Covid-19 has thus been 'hotspotted' to realms of tropicality, although also in this case to illicit trades that have flourished in the wake of China's market liberalisation of the 1980s. 
eTropic 20.1 (2021) Special Issue: Pandemic, Plague, Pestilence and the Tropics

While the reach and grip of the virus is fundamentally microbial, writers such as Liu (2020) point to its entanglement with what Césaire saw as 'daily barbarisms' of capitalist-colonialist violence (also Swatuk et. al., 2020). Césaire argued that the choc en retour of colonisation was rooted not simply in grand spectacles of imperial power, but also, and in many respects more fully, in myriad everyday acts, routines, circuits, banalities, insinuations and exonerations of power and ideology, and acquiescence to them - to create a continuum power and a corrupting of normality that both makes, and is made by, la quotidienneté des barbaries. Daily barbarisms, he continued, have a circulatory logic as well as an oppositional shape and they were integral to how, in his day, the supreme barbarism of Nazism and the Holocaust came about. He deployed this expression to flag an everyday chipping away at the association of normality with civility - a chipping away, and of letting the rot set in, that would eventually, and with an unforeseen yet unsurprising bang, expose the lie of this association and reveal how it was routinely and discreetly (or always already) liable to be translated into more sinister things, into uncivility in the name of progress (6 January 2021 on Capitol Hill is a day upon which to remember this lie). For him, this chipping away took place in disparate ways and places, and with words and referents that were attuned to capitalist regimens of boom and bust, and accumulation and inequality, as well as colonialist and fascist regimens and fantasies of mastery and subservience, divide and rule, and annexation and elimination.

Among other things, Césaire was thinking about taken for granted, and putatively ineluctable, racial-capitalist processes of production, consumption, distribution and exchange. As the 2018 Yearbook of the data-driven Trase (Transparency for Sustainable Economies) platform surmises, since the 1960s (i.e. since decolonisation and since Césaire wrote) there has been a fourfold increase in the volume of agricultural commodities exported from tropical countries: beef and timber, and especially so-called 'flex crops' such as soy, palm oil, sugar cane, and maize, which are "prized in the global economy for their versatility" (to be used as food, animal feed, biofuel, and for myriad other commercial purposes) (Trase 2018). There has been a dramatic expansion in and intensification of commercial farming, crushing biodiversity and stripping ecosystems and their antibiotic stores. Profit-fixated and planetplundering capitalist connections are disguised within global supply chains, the traffic in commercial staples, and a boom in illegal trade, all of which ramp up environmental rift. No wonder Liu (2020) urges that "the best safeguard against the novel coronavirus is the ability to voluntarily withdraw oneself from capitalism."

Césaire's choc en retour revolves around a double surprise of resistanceacquiescence and shock-vigilance. He arrived at this view via the following route. Decolonisation was the central political question and existential venture of his day, 
eTropic 20.1 (2021) Special Issue: Pandemic, Plague, Pestilence and the Tropics

and one that in recent decades has swung fully back into view. For Césaire, decolonisation was integral to the question of what it means to be human: more specifically, to how unfreedom is rooted in human prejudice, disdain and cruelty, and has been actualised through racism, slavery, and the loss of place and identity to the coloniser. This was what needed to be said about and against empire, he urged. And yet whenever and wherever the colonised set themselves up in this way, en face de la colonisation, with words and deeds emitting a spirt of resistance and thirst for independence, it came as a shock (both a surprise and an affront) to the coloniser, who, in turn, responded with the refrain 'it is not in our nature to be that bad', and certainly never as wicked as Hitler.

Colonisation "dehumanizes even the most civilized man", Césaire declared. Even the most "reasonable man [sic] gets into the habit of seeing the other man as an animal, accustoms himself to treating him like an animal, and tends objectively to transform himself into an animal" (Césaire 2000, p. 20, 41). Moreover, one always needed to watch out for this accustoming because its effects ran deep. Vigilance is needed with respect to how fluidities and exchanges - and, with them, resistance and new possibilities - get sealed back up in boxes of climate and race, temperate and tropical, citizen and subject, capital and commodity, and what Mbembe today sees as a global colonial present that is "undeniably one of separation, hate movements, hostility, and above all, struggle against an enemy" (2019, p. 23).

For Césaire, Western presumption and protectiveness around its 'temperate' nature was betrayed by the way the 'tropics' served as its other. This, for him, was at once a capacious scandal and an open secret that the West had always sought - but struggled to hide - because it exposed the primordial and beastly hand of bigotry and wanton violence in its affairs. Accordingly, he argued that decolonisation needed to be construed as an incessant struggle because the visceral (animal and instinctive) malaise and injury wrought by colonisation ran deep, and since high-minded Western aficionados of liberty and objectivity continued to domineer and distort understanding as empire wound down. Racism, especially, was at once an obstinate postindependence reality and a symptom of a deeper circuitry of power and people's acquiescence to it. Written in the wake of the Nuremberg trials, as well as at the tail end of empire, Césaire's comparison of colonialism and Nazism via la quotidienneté des barbaries was, as Gary Wilder notes, a way of saying that "Europeans were less concerned with crimes against man [sic] than with crimes against white men", and that in long tolerating colonialism such 'concerned' people had been "accomplices" of Nazism (the supreme barbarism) before they had become its "victims" (2015, p. 128).

Césaire was grappling with a continuum of power which is still regimented in daily acts of consumption and environmental destruction to which people the world over are 
eTropic 20.1 (2021) Special Issue: Pandemic, Plague, Pestilence and the Tropics

habituated but from which they struggle en masse to withdraw. The profits of some, the subsistence and very survival of many, and aspirations of all, are caught up in practices that today not only have profit- and subsistence-busting consequences, but also threaten life on earth itself. Césaire sought to expose how the imperial West was a smooth operator in this regard and sold its operation to others. "Wherever there are colonizers and colonized face to face", he wrote, "I see force, brutality, cruelty, sadism, conflict", but also "and, in a parody of education, the hasty manufacture of a few thousand subordinate functionaries, 'boys', artisans, office clerks, and interpreters necessary for the smooth operation of business" (Césaire, 2000, p. 42).

That the effects of such education and operations - the rudiments of 'business as usual' in climate change language and models - on earth systems, and in the form of new zoonotic diseases, are represented as a shock and continue to be externalised and disavowed as antithetical to 'the usual' would not have surprised Césaire. He was mindful of what Stuart Hall (1996, p. 249) would later describe as "the over-determining effect of the colonial moment, the 'work' which its binaries were [are] constantly required to do to re-present the proliferation of cultural difference and forms of life" in hierarchical "the West and 'the rest"' terms. For Césaire, this over-determining work was rooted in race and the way it leached into geography and environment; and it called for constant vigilance with regard to how the sources and sway of malaise were disguised within a modernity that defined itself as expository, enlightening, progressive and transformative.

Tropicality both exposes and disguises this chipping away, and two glimpses, hewn from Césaire's time, of how this happens will hopefully suffice to make the point. On the one hand, Britain's wartime leader Winston Churchill (and hero of the UK's hapless current Prime Minister), opened his famous 1946 speech in Zurich about the need for common European resolve (and perhaps even integration - the shock!) following the colossal "tragedy" that had befallen the continent, with the hope that order and happiness might return through the recognition that "this noble continent, comprising on the whole the fairest and the most cultivated regions of the earth; enjoying a temperate and equable climate, is the home of all the great parent races of the western world" (CS, 1946). Churchill offered a temperate volte face to the misery and destruction of war, while deflecting the issue of how and why Europe's 'temperate' edifice had been punctured so profoundly by 'uncultivated' passions and hostilities.

On the other hand, Césaire's tropicalité involves a jouissance of difference as well as crushing alienation. It is partly about the potential for radical renewal of the self. He pursued this vision in the wartime literary review, Tropiques (1941-1945), which he launched with his wife Suzanne Roussi, and René Menil, in his native Martinique and under the prying eyes of Vichy censors. The magazine brought Césaire's broader 
eTropic 20.1 (2021) Special Issue: Pandemic, Plague, Pestilence and the Tropics

project of négritude to the French Antilles and, to be sure, toyed with exoticism and primitivism. But Césaire maintained that it was insurrectional: a way of questioning how Vichy France had woven images of tropical grandeur and excess into its patriarchal imagining of a 'greater France' and fascist Volk.

However, Césaire was under no illusion then - and nor would he have been now about the manipulative means and ends of tropicality. In a notable 1945 contribution to Tropiques entitled "La Jungle", Pierre Mabille, a confidante of surrealist André Breton, anticipated elements of what was soon to come in Discours sur le colonialisme declaring that "tropical paradises suppose the existence of prisons", and that people faced an opposition and choice between

the jungle where life explodes everywhere, free and dangerous, the most luxuriant vegetation being full of all kinds of mixtures, transmutations and trances, and that other sinister jungle where a Führer, perched on a pedestal, watches...the departure of mechanised cohorts that are ready, after having destroyed all other living things, to annihilate themselves in the rigorous parallel lines of endless cemeteries. (Mabille in Césaire \& Roussi, 1978, p. 187)

For Césaire this 'sinister jungle' was a disparaged, self-imprisoning and fatal world.

Moreover, behind the Nazis were legions of putatively more temperate (rational, objective) experts and scholars - legions of 'daily barbarists', if you will. Césaire picked (among others) the French doyen of the field of tropical geography, Pierre Gourou, to make this point (see Boyd \& Clayton, 2019, pp. 1-35). He contended that the "subjective good faith" of liberal Western academics like Gourou was "entirely irrelevant to the objective social implications of the evil work they perform as watchdogs of colonialism" (Césaire, 2000, p. 34). Gourou was right, Césaire acknowledged, to mount a sustained critique of environmental determinism (which was a bête noir of his discipline of geography). However, Césaire objected to the prejudice masquerading as objectivity in this geographer's deterministic judgement that great civilisations had only ever existed in temperate climates, and that while temperate civilisations had influenced (for good and ill) tropical ones, the reverse did not hold. Consequently, Césaire lambasted that "if tropical countries are not under the biological curse of the racists, there at least hangs over them [for Gourou], and with the same consequences, a no less effective geographical curse" (Césaire 2000, p. 34).

To end this section and start to bring this discussion back to the UK and today, Césaire's choc en retour is about both surprise and delay, and climate change and 
eTropic 20.1 (2021) Special Issue: Pandemic, Plague, Pestilence and the Tropics

Covid-19 loom in this way too, as both instantaneous/acute crises and protracted eventualities/menaces. There is a vexed futurism to what a group of leading environmental scientists (Bradshaw et. al., 2021) describe as the "time delays between ecological deterioration and socio-economic penalties": vexed in that while "the window of opportunity" for doing something about rapidly deteriorating planetary conditions may be closing fast, these time delays encourage hesitancy and fracture resolve to act right now and at the scale required.

Covid-19 was perhaps a zoonotic disease disaster waiting to happen, and it now comes with a 28-day warning. Twenty-eight days is the 'life span' of the virus from a biopolitical point of view: the time between infection and death as it is determined and recorded on death certificates in the UK and other countries - "Deaths within 28 days of positive Covid-19 test by date of death" (PHE, 2020). This time delay also regiments political decision-making and public perception. It is what is suspended between infections (as detected by testing, tracing and population surveillance mechanisms); decision-making and behaviour change in response to surges and declines in infection rates (chiefly via the tightening and loosening of lockdown restrictions); hospitalisations (and the capacity of health systems to cope with them); and deaths (in $2-4 \%$ of recorded cases globally).

This Covid-19 time frame stalks governments around the world. It lies at the heart of the issue of whether they have been deemed to act (lock down) fast and hard enough when the evidence warranted it; how they have sought to both save lives and preserve livelihoods when these two aims pull in opposite directions; and whether they are 'seen to be following the science' (which is driven by epidemiological modelling around an arcane scientific term, the ' $R$ [reproduction] rate', which has swiftly accrued ominous existential relevance).

\section{La Quotidienneté des Barbaries of Climate and Disease}

Times have changed but as some of the above suggests the implications of Césaire's choc en retour perhaps have not. In fact, his boomerang effect can be tracked out of the year, 1950, in which Discours sur le colonialisme was published. This year is noteworthy for three reasons - the first two climate related, the other disease related. First, it was the initial year in which the storms of the Atlantic hurricane season were named, by the US military (a taming of storms from a temperate clime), and with the strongest storm of that year, Hurricane Dog (early September) battering Césaire's Martinique (and eventually causing havoc in Scotland, from where I am writing this article). Second, and as Chakrabarty intimates, 1950 is often used as a baseline for the 'great acceleration' in environmental and human indicators associated with what has become called the Anthropocene. And third, 1950 (and spilling into 1951) was 
eTropic 20.1 (2021) Special Issue: Pandemic, Plague, Pestilence and the Tropics

also the year of the last major influenza epidemic (A/H1N1) to hit the UK (and North America), although with deaths not nearing those of either the 1918 flu pandemic or Covid-19 (Hagan et. al., 2012; Viboud et. al., 2006).

The choc en retour of Covid-19 and climate change works in perceptual (cultural, political) as well as material (economic, ecological, biological) spheres, and I shall now probe them further in two strokes, the first climate-oriented and the second diseaseoriented (although with overlaps between them), and again with the UK as my main example. But before I start, a general point might usefully be glossed.

The media (print and now televisual and digital media) has played an overarching and decisive role in framing how disease 'outbreaks', weather extremes, environmental calamities, regimens of risk, and expressions such as 'global warming' and 'climate change' have been presented to the public. Hence my extensive use of news media, and science and political journalism and blogging, as forms of storying. As Katherine Foss (2020) shows in Constructing the Outbreak: Epidemics in Media and Collective Memory, disease 'outbreaks' are visceral and deeply personal yet not fully knowable or liveable outside of the stories, statistics, news spectacles and languages used to convey and categorise their meaning and impact. This realm of representation plugs people, politicians, scientists, and public memory into webs of identity, allusion, duty and accountability.

As Foss also suggests, and the UK's august medical periodical, The Lancet, relayed as Covid-19 began to appear in the country, "Outbreaks create fear, and fear is a key ingredient for racism and xenophobia to thrive. The coronavirus disease 2019 (COVID19) pandemic has uncovered social and political fractures within communities, with racialised and discriminatory responses to fear, disproportionately affecting marginalised groups" (Devakumar et. al., 2020). Jack Zhou (2016) adds that there are also divisive (class-based and racialised) "javelins" as well as "boomerangs" in public communication over climate change. Within both disease and climate reporting, the word 'normal' is mediatised as at once a placeholder and a projection, and the way 'normality' is constructed and claimed is of great significance.

To return briefly to the conceptual spot where this article began, Arnold's presumed normality of the northern temperate zone - the cornerstone of tropicality - is about who gets to decide on what counts as a 'normal' (and right and true) nature, climate and life, and who and what does not. This 'who' enacts an elsewhere and other by dissimulating, however impossibly or unsuccessfully, the process by which it arrogates normality to itself. In turn, this somewhere/something else is enveloped as it is performed as an outside, and often with fear and loathing of the exotic and the foreigner at the forefront of signification. To refer to Homi Bhabha's (1994, p. 3) still 
eTropic 20.1 (2021) Special Issue: Pandemic, Plague, Pestilence and the Tropics

timely formulation about "how newness enters the world" and "normality" captures it, the adjective and adverb 'new' in 'new normal' does more to mask and disavow than it does to acknowledge or negotiate "the 'right' to signify [otherness, newness, aberration or hybridity] from the periphery of authorized power and privilege" including peripheries of climate and disease. The "power of tradition" - i.e. normality - is "re-inscribed through the conditions of contingency and contradictoriness that attend upon the lives of those who are 'in the minority"' - including those placed there by virtue of leading 'anomalous' lives in 'extraneous' disease or climate circumstances.

\section{In the Tracks of Extreme Weather}

"As we progress through the peak of the 2020 cyclone season", The Lancet reports, it is important to note not just that "evidence continues to mount that climate change is making tropical systems stronger...wetter...and slower forward moving when they come onshore", but also that "the COVID-19 threat will intersect with the growing risk from extreme storms, spurred by global environmental climate change". As "climate change modifies the behaviour of tropical cyclones", the report continues, "human health is imperilled for storm-impacted communities", and with "more injurious and traumatising storm hazards... having disproportionate effects on the most vulnerable." Relief workers will be in "double danger." The Gulf of Mexico and southern states of the US, along with Japan, South Korea and Taiwan, are destined to bear much of this brunt, and while most countries in the world now have storm alert and protection systems, this "compound-threat scenario" presents a new "threat level" (Shultz et. al., 2020, pp. 506-508).

The authors of this report are based chiefly in Florida and the implication is that the stakes get higher, and there is more to lose, the closer these super-charged storms move towards 'temperate' lands and their industrialised economies, urbanised landscapes and dense infrastructures. Meanwhile, other scientific reporting in this riskthreat vein is vehement in its criticism of the way such 'evidence' is presented as if it is uncoupled from underlying drivers, or anthropogenic 'daily barbarisms', of fossil capital, capitalist creative destruction, and the coloniality of an expendable nature (e.g. Collett et. al., 2017; Malm, 2020).

In other words, extreme weather threats, and the 'risk maps' into which they are plugged, are both real and imagined. Global knowledge of climate change "has distinctive geographies", Martin Mahoney and Mike Hulme (2018, p. 395) reflect, and ones "shaped by histories of exploration and colonialism, by diverse epistemic and material cultures of knowledge-making, and by the often messy processes of linking scientific knowledge to decision-making within different polities." The naming of tropical hurricanes, started in 1950, helped to domesticate the threat they posed via 
eTropic 20.1 (2021) Special Issue: Pandemic, Plague, Pestilence and the Tropics

procedures of scientific forecasting and financial (property, insurance, investment) planning, albeit with the names still granting each one an individual shock value.

It might be averred, in a wider sense, that the relationship between climate change and extreme weather swirls around two 'tyrannies'. On the one hand, there is what David Livingstone (2012, p. 91) terms the "tyranny of the mean", with what is regarded as 'normal' or 'abnormal' about the weather articulated in a language of averages, parameters and trends over shorter and longer periods of time. This "tyranny", he continues, has "conspired to keep hidden climate as it is actually experienced by individual people in specific places", which is often in terms of dramatic events rather than patterns or tendencies (also see Spicer, 2016). On the other hand, there is the tyranny of dogma and alarmism around climate change, which, as Rupert Darwell (2017) seeks to show, links different green and grimy "tyrannies" - ones of industrialisation, consumerism, energy exploration, and different forms of environmentalism and conservationism.

Over the last few decades, the UK's national weather service, the Meteorological Office (Met Office, est. 1854), has been placed ever more firmly in the public spotlight as an authoritative source of information and medium of communication. The Met Office has been particularly forceful recently in attempting to dissolve the distinction between extreme weather, which has a folkloric status in the British psyche (the British love to talk about the weather!), and the idea of "climate change" as an outside threat. The latter is collapsing in on the former, the Met Office (2018) notifies, in that climate change is making extreme weather both more extreme and more regular. The one can no longer be separated from the other, and it has been through Met Office reporting that the newspaper media has latched on to the expressions "tropical days" and "tropical nights" to describe the UK weather (McGrath, 2018).

Since the start of the millennium another of these tyrannies has surely been the resurgence of environmental determinism in the public imagination and policy domains (see Meyers \& Guss, 2017). For example, in a 2001 article entitled "Tropical Underdevelopment" prominent United Nations adviser Jeffrey Sachs resurrects the idea that "Perhaps the strongest empirical relationship in the wealth and poverty of nations is the one between ecological zones and per capita income. Economies in tropical ecozones are nearly everywhere poor, while those in temperate ecozones are generally rich." The roots of tropical backwardness and underdevelopment, he continues, as if such language was still permitted, lay in "the combination of physical ecology and societal dynamics", and it is to the science, technology, investment and governance of the temperate north, he goes on, that the tropics will need to look for salvation (Sachs, 2001, p. 2-5). In a recent Scientific American op-ed, climate scientist Simon Donner (2020) reports, bluntly, that "When you perform a Google Image search 
eTropic 20.1 (2021) Special Issue: Pandemic, Plague, Pestilence and the Tropics

for 'victims of climate change,' the faces you see are those of Black and brown people in the tropics", and with images of "small reef islands in the Pacific Ocean, arid landscapes in East Africa and flooded villages in South Asia" abounding. The "ugly history of climate determinism" to which such imagery pertains "is still alive", he urges, and is rooted in "our implicit biases about people living in different regions of the world".

Gourou (1963, p. 10) lamented the traction of such views and his observation, from the early 1960s, still holds up: "Is it not interesting to recall the views of Montesquieu, for do they not live in us, and still readily come to life, as they lived in him? Have we come to a more correct observation than that in the time of Montesquieu [mid eighteenth-century], that the people of the north are taller, calmer, more hardworking, more honest, more enterprising, more trustworthy, more interesting than people from the south?" Since Gourou wrote, more hospitable and non-reductionist environmental discourses and fields (of environmental economics, political ecology, conservation, and so on) have arisen. Over the last sixty years, however, a more simplistic and malevolent language of environmental determinism has also persisted.

"Extreme weather events and off-kilter weather patterns are causing more humanitarian crises and fuelling civil wars", Christian Parenti sets out to show in his Tropic of Chaos, especially "in that violent and impoverished swath of terrain around the mid-latitudes of the planet" (2011, p. 9). He uses 'tropic' as a locational metaphor for breakdown and threat, and to flag a "catastrophic convergence...[of] political, economic and environmental disasters" associated with "a belt of economically and political battered post-colonial states... [where] we find clustered most of the failed and semi-failed states of the developing world" (Parenti, 2011, pp. 6, 9-11). Cold War militarism, unfettered corporate plunder, neo-liberal restructuring, and 'banana wars' (guerrilla insurgencies) have all played a part in the creation of this 'tropic of chaos' a corruption-, disease- and famine-ridden zone - he thinks; but regardless, the association of 'tropic' and 'tropics' is tight, and for Parenti, as for Sachs, the onus is placed on the 'temperate' West to sort out the chaos. While providing a dramatic picture of the concatenation of factors afflicting 'the tropics' - and disclosing what Sachs (2018) sees as the close links between "climatic shocks and extreme social instability" - Parenti rehearses a powerfully disparaging and pessimistic narrative, and his 'tropic of chaos' is one of Western angst.

If much of this seems like a strained, even desperate, attempt to somehow keep a 'tropic of chaos' on the outside, it is because the idea of neatly separated temperate and tropical zones - of a normalised tropicality - is becoming increasingly scrambled. What were once deemed 'normal' attributes of tropical nature and constitutive of its alterity - constant heat and moisture in some areas, pronounced wet and dry seasons in others, and intense weather events and vulnerability to storms, floods, droughts, 
eTropic 20.1 (2021) Special Issue: Pandemic, Plague, Pestilence and the Tropics

and wildfires - now permeate the temperate north. A tropicality that is fraught with an "ugly history of climate determinism", as Donner (above) puts it, is now overlaid, and in some ways overwhelmed, by a more universal sense of climate vulnerability and victimhood. The implications of this recognition are dire, to say the least: humanity is rapidly running out of the time it may need to tackle a "ghastly future" for the biosphere and life on earth; "the mainstream is having difficulty grasping the magnitude of...the existential threats tied to the continuous expansion of the human enterprise" (Bradshaw et. al., 2021).

Mahoney (2016, p. 14) suggests that climate change "has arguably shifted discourses of tropicality from themes of colonial encounter to speculation about tropical invasion". In the Anthropocene, human populations around the world are "jointly engaged in the ongoing composition of a common, climate-changed world" in which an older geographical imagination of "tropical nastiness" is supplanted by "mobile climates" climates through which volatility and viciousness migrate, circulate, and are lodged in places hitherto deemed to be shielded from them. The locational markers of a 'tropic of chaos' are becoming more irresolute. Different temperate and tropical actors, constituencies and entities - states, cities, farmers, fire services, forests, river basins, coastlines, crop and irrigation systems - are now enveloped by processes that were once represented as specific to the tropics and as merely parroted in temperate lands, in botanical gardens and at world exhibitions, for example. A group of climate scientists led by Paul Staten and Jian Lu (2018, p.768) have synthesised an array of observational data to "reveal a poleward expansion of the tropics in recent decades, implying a potential role of human activity...; the tropics are found to have widened about $0.5 \%$ of latitude per decade since $1979 . "$

In short, climate change, and other processes dubbed 'extreme' or 'widening' in their effects (disease, populism, terrorism), are working to fracture the hoax that danger, difficulty and despair simply dwell elsewhere. "We are all climate refugees now", Sachs (2018) declares. But to what ends will such ideas be put? Césaire would say that vigilance is required.

\section{Disease Wars and Sites/Sleights of Memory}

In Sites of Memory, Sites of Mourning, Jay Winter (1995) explores the sensitive and highly personal issue of how people dealt emotionally with the scale of death and trauma wrought by the Great War, and in most cases without having an opportunity to 'say goodbye' to loved ones, neighbours and friends who were felled by guns, germs, gas and steel in distant trenches, and from which bodily remains were never returned. The stark visiting restrictions around Covid-19 hospital wards and funerals have resurrected this trauma of being 'unable to properly say goodbye' and of the 
eTropic 20.1 (2021) Special Issue: Pandemic, Plague, Pestilence and the Tropics

inadequacy of established (modern/state) ways of mourning for dealing with the scale, speed and disbelief of loss. While the Great War and Covid-19 might both be studied as supreme cruelties that are connected to myriad daily barbarisms, the 'unpreparedness' that is a marker of loss in both cases also flags limits and losses of memory, and perhaps more so in the case of Covid-19. Winter shows that while people struggled with loss after the Great War, there were still patchworks of tradition regarding death upon which they could fall back - much more so than today - and people then lived in closer proximity to death (in terms of life expectancy and the spectre of disease).

1950 was the last time the UK was hit by a flu epidemic on a scale approaching that of Covid-19 (although the polio threat of this era was of longer-lasting significance), and this 1950 flu was arguably more easily abated and with much looser restrictions than those of today because people and places then were less mobile and interconnected. Behavioral scientists think that the UK public and Government is at something of a loss to know how to cope with Covid-19 because a disease and death threat of this magnitude is no longer part of collective memory (see Hall \& Ross, 2020). In recent decades the UK has had public health 'scares' with HIVIAIDS, 'Mad Cow Disease,' and 'Bird flu', but they have worked in a different biopolitical register than Covid-19. In spite of being deemed ominous public health problems, and instilling utter dread (especially HIVIAIDS), the political gambit, to which the public was soon acquiesced, was that these infectious inroads into the general population came chiefly from specific practices and sectors of the population (HIVIAIDS was initially and speciously dubbed a 'gay plague') and that, with requisite psychological and behavioural cordons sanitaire and 'de-risking' behaviour, could be contained within them. De-risking from the airborne Covid-19, and for which asymptomatic transmission is key, is a formidable challenge, largely because everything about daily life - work, home, consumption, leisure, travel - is susceptible to it.

And it shows: in the UK annual deaths from HIVIAIDS peaked at around 2000 in the mid-1990s, compared with 1500+ deaths per day from Covid-19 (Euronews, 2020). December 2020 was the start of a 'second wave' of Covid-19 in the UK, and one far more lethal than the first, with over 40,000 in hospital with the virus at its February 2021 peak, and currently with a total of over 125,000 deaths, although vaccines now bring a new and hopefully decisive "weapon" in the "war" against Covid-19, as the country's tackling of the virus has been described (PHE, 2021).

Césaire censured the political short-termism and blasé consumerism of the imperial West, and how it turned a blind eye to the injurious long-term effects of its routine human and environmental exploitation - barbarisms. It might be argued that much of the perceptual shock and unpreparedness surrounding Covid-19 stems from this 
eTropic 20.1 (2021) Special Issue: Pandemic, Plague, Pestilence and the Tropics

blindness. Over time it has made Western governments and populations increasingly ill-equipped to cope with anything that disrupts their mobile and finely-tuned lifestyles. The moment at which Césaire pointed to this - again, 1950 - is instructive, especially in the UK case. Imagery of Covid-19 as 'the end of a way of life' comes with allusions to something prior and now putatively lost: to estrangement from national fortitude, resilience and stoicism in the face of adversity. In the UK, 'the war' (as World War II is often simply described), and an associated Blitz - 'we just got on with it' - spirit, is invoked in the present Covid context as the last time the country was truly put to the test, but the over 80 s are the only group left with any direct connection to this time and disposition (Jones 2020).

Georgina Endfield (2019, pp. 2-5) applies a similar sentiment of loss to the weather. "Climate knowledge, experience, and memory are all necessarily situated", she argues, and have hierarchical and contested histories and geographies that have "contributed to comprehensions of place-specific cultures, local identities, and changing articulations of place". Yet as places lose their local "weather heritage" due to a combination of meteorological science (weather forecasting and Livingstone's 'tyranny of the mean'), human mobility, and artifices of modern life (central heating, air conditioning, architectural design, and so on) the question of how such heritage might today "serve society and communities at a time of uncertain weather futures" becomes elusive.

In Plagues and Peoples, William McNeill (1976) observes that epidemic disease 'does not discriminate' (another mantra we hear today), and that responses to it have been shaped in the image of the societies it afflicts. He had in mind the epidemics of smallpox, measles and influenza that decimated the indigenous populations of the Americas within the first one-hundred years of Columbus's 1492 landfall. If there is a maxim about plagues, he suggests, it is that they have a disproportionate impact on the disadvantaged and vulnerable segments of societies. Such, it is now clearly documented, is the case with Covid-19. As the UK's top epidemiologist, Neil Ferguson (cited in McKie, 2021), whose modelling of the virus was pivotal to the timing of the country's first lockdown, reflects:

What is paradoxical is the fact that the UK has punched well above its weight...in understanding the virus - yet we have the worst per capita mortality from Covid-19 in the developed world.... The poor have been worst affected in multiple ways. They have the lowest job security and have the least ability to work from home. They tend to work in frontline professions where they are more exposed to the virus. They also tend to have poorer health and have more co-morbidities so that they get more severe reactions to Covid and suffer higher mortality rates. 
eTropic 20.1 (2021) Special Issue: Pandemic, Plague, Pestilence and the Tropics

In short, the virus preys on inequality. Mortality rates are more than two times higher than the national average in deprived areas of the UK, and these areas are also, generally, the most densely populated and polluted parts of the country, and ones with significant BAME (Black, Asian, Minority Ethnic demographic category) populations (see e.g. Dorling, 2020). In these and other ways, the UK Government's retort that "we are all in this together" - another facet of the 'Blitz spirit' noted above - does little to soften the loss and sorrow that has befallen families and communities. In fact, it only serves to highlight the crucial qualifier offered by Ed Conway (2020), that "some of us are in this more than others".

Within all of this, old habits of tropicality not only die hard but have also long been entangled with militarism. NHS staff (as well as American and other European health workers) are commonly referred to as "frontline workers"', with the military connotations of the expression barely noticed (Poole, 2020). During the first wave of the pandemic in the UK, government ministers were drilled to tour the TV news studios with the message that "we are in a war against an invisible enemy" and one "in which every one of us is directly enlisted" (see Shariatmadari, 2020). This is part of the economy of surprise, and as Mbembe (2020b) updates Césaire's outlook: "Not knowing what is to come [with the virus] is what makes states all over the world resurrect the old terminology utilized in war".

In the UK (albeit not just there) war metaphors and allusions have been used to deflect the amateurism and incompetence of the government's response to the virus (although the devolved Scottish Government's efforts have arguably been more efficacious). Ineptitude marked this response from the outset, when the Prime Minister Boris Johnson loitered on holiday on the private tropical island of Mustique as the virus took hold of the country; and it ensued with a $£ 22$ billion test-and-trace scheme that he declared was "world beating" but, it now seems, has done little to reduce coronavirus infection levels (Syal, 2021). Philosopher Jean-Luc Nancy (2020) thinks that a "sort of viral exception - biological, computer-scientific, cultural - which is pandemic" is at work, with "governments...nothing more than grim executioners"; and so "taking it out on them seems more like a diversionary maneuver than a political reflection." However, Nancy's remark does not detract from the need to think about the metaphors and allusions by which politicians live.

The use of military tropes is mediated by a mindset of both vulnerability and protection: one that does not pertain solely to the UK, but of which Brexit, in the British case, is a prime symptom. The UK is an imagined island country that emits the idea that it is protected from excesses of climate and ravages of disease, while leading the battle to study and conquer them. "The U.K. is a world leader in preparing for and managing 
eTropic 20.1 (2021) Special Issue: Pandemic, Plague, Pestilence and the Tropics

disease outbreaks", the UK's (now shell-shocked) Health Secretary, Matt Hancock, sought to reassure the nation in March 2020, and he continued, the UK Government has a "battle plan" (2020b). In France, too, militarism quickly became a form of political messaging (Opillard et. al., 2020). There was a brief switch in language in the UK when Johnson returned to public life after being hospitalised with (and nearly killed by) the virus in April 2020. He came back with the more personalised message that the country was now "tackling an unexpected and invisible mugger". Covid-19 had broken into the body politic and was trying to run off with its chattels. But the martial metaphors soon crept back in, and with Johnson using increasingly odd references to war films to justify subsequent restrictions (York, 2020).

There is of course a much longer and wider militarisation of disease and medicalisation of war, upon which there is insufficient space to dwell here. Suffice it that environmental economist Edward Barbier (2020) is by no means the only observer to turn matters on their head and ask: "are tropical ecosystems the new frontline" in the "war" against Covid-19 (also see Rainforest Alliance 2020)? Such performances have been folded into Johnson's 'war', and as scholars linked to the Brookings Institute (Belin et al., 2020) suggest, the "war" against Covid-19 is putting "politics under anaesthesia", especially in the UK, France and the US.

Remarkably little has been made of how this war and enemy is steeped in what I have called the "militant tropicality" of jungle warfare that imbued the post-war era of decolonisation (Clayton, 2013). The British in Malaya, French in Indochina, and Americans in Vietnam (to name just the most conspicuous of these 'militant' domains) found themselves fighting 'irregular wars' against invisible enemies and with no clear military frontlines - a far cry from fighting in the 'temperate' battlefields of Europe and facing guerrillas who extracted maximum strategic advantage from the tropical environments in which they operated (also see, e.g., Jericho, 2005). The American private telemedicine practice Sliiip (2020) alludes to this, observing

we have recognized guerrillas - the Viet Cong, the Tamil Tigers, and recently, the Taliban - frustrate and humiliate larger forces by discretely invading territories, co-opting locals and being seemingly resistant to traditional warfare offensives. Equally, our public health institutes, gleaming hospital buildings, expensive diagnostic machines, a legion of administrators and medical personnel have been humbled (and humiliated) by this virus. Our fragmented healthcare industry is now united by a microscopic organism, as competing systems share laboratory testing and treatment protocols while hospital leadership cross battle lines to share guarded patient census and drug availability information. 
eTropic 20.1 (2021) Special Issue: Pandemic, Plague, Pestilence and the Tropics

On the other hand, Thuy Dinh (2020) informs the American public that "what the coronavirus and the Vietnam War share" are "home-schooling, distancing, fearing for your life... Sheltering in place during the Tet Offensive prepared me to cope with the coronavirus today."

The anonymity - invisibility, irregularity and capriciousness - of contagion and calamity, and, again, especially the asymptomatic nature of Covid-19 transmission, at once confounds the use of war metaphors to comprehend what is happening, and reignites recognition of what WHO figureheads Máire Connolly and David Heymann (2002) neatly describe as the long-lived ways in which wars and infectious diseases have been "deadly comrades", both inside and outside the tropics.

Covid-19 is not the only threat or crisis to be shrouded in this language of war. Prime Minister Johnson has applied war metaphors to domestic politics and the UK Brexit negotiations too. As Lea Ypi (2019) observed on the eve of the pandemic: "The theory of war in international relations is premised on recognising the symmetry between belligerent parties whilst registering the responsibilities of all sides. War is what nations resort to when they have run out of ways to negotiate." But the metaphorical mobilisation of war in politics conspires to turn "political adversaries into enemy targets", and the insinuation today that there is some negotiation to be had with a super-charged earth system and rampaging virus only serves to deflect understanding of how these eventualities work.

A year on, and yes, the UK Government's 'battle plan' has had some traction: there are effective vaccines which are being rapidly rolled out. Yet still, commentators now carp that vaccination itself "should be treated as if it were a war" (to be administered with military precision), and articulation of this facet of the "war against an invisible enemy' is now supplemented by talk of "vaccine wars" between countries and regions (between the UK and European Union, for example) (BBC, 2021; Otte, 2021). Nor, to round this off, has the immediacy of the Covid-19 crisis in the UK caught up with creeping awareness over preceding years that, as the country's most widely read tabloid, The Daily Mail (2012), helpfully put it, "The tropics are moving northwards and the bad news for Britain is it means MORE rain for US" (heatwaves and storms are mentioned too).

\section{Plagued by Tropicalité}

This article has sought to track the intertwining of 'temperate' and 'tropical' in the trajectories and tragedies of Covid-19 and climate change - calamities that are placing the present in a storm of trepidation with neither eye nor end. It has sought to do so, 
eTropic 20.1 (2021) Special Issue: Pandemic, Plague, Pestilence and the Tropics

principally, with an interest in how climate and disease perils that have hitherto been earmarked as 'tropical' are permeating the 'temperate north' - areas that have deemed themselves to be closeted from weather extremes and the ravages of epidemic (especially zoonotic) disease. This story has been pursued chiefly (although not exclusively) with reference to the UK, as one such 'temperate' place whose myopia, amnesia and vulnerability in this regard is currently exposed.

The attempt here to get at something of tropicality's temperate 'inside' as it rasps for a tropical 'outside' provides just one route into Covid-19 and climate change. Nor, I should reiterate, have I been talking about, or for, either the entire population of the UK or a more nebulous temperate West. Rather, I have been concerned with the collocation - and in the case of the UK, intensity - of both recurring and startling notions and metaphors in politics, science, and the media. The theme of tropicality facilitates understanding, I think, of how Covid-19 and climate change have been represented as 'shocks' to the UK and other 'temperate' places that have customarily regarded themselves as immune to the exactions and traumas associated with such problems. 'Temperate' places like the UK now struggle to signify themselves in this way while continuing to do so, out of habit, or perhaps (to follow Jean-Luc Nancy) as a survival reflex (and with the political capital this might entail still obscure). The fright and distress now wrought by the virus and climatic calamity on the metropole might be deemed the choc en retour of centuries of colonising and tropicalising - a boomerang effect of the exactions and traumas, and allure and abjection, that have long been made to adhere to 'the tropics'.

The war reflex discussed above is one sign of this crisis of signification and boomerang effect. It is, of course, the job of 'frontline' health workers to occupy the body line between immunity and contagion (as well as that of the soldier to put her/his body on the line between life and death for nation, and formerly empire). As Christine Chinkin and Madeleine Rees (2020) note, in these ways and more, militarism is "a default position" in the language of politics that pre-dates Covid-19. However, over the last year, they point out, militaristic soundbites have been ramped up. These soundbites create an allusion of 'being in this together' when 'we' really are not, and of nudging us to "get behind our 'fearless' leaders (male) who hold power and not to seek answers to our questions [about their decisions and incompetence] until we have 'beaten' this enemy."

Btihaj Ajana (2021) adds that "immunity is precisely what bridges... biological life and political life in the current [Covid-19] climate, be it in terms of the contentious notion of herd immunity, the geopolitical struggle for vaccines, or the possible emergence of a 'Covid-elite', i.e. holders of so-called 'immunity passports'." Immunity is "certainly not 
eTropic 20.1 (2021) Special Issue: Pandemic, Plague, Pestilence and the Tropics

only a matter of science and biology alone, but is inherently political in the way that pandemics themselves are often highly politicised."

One of the aims of this article has been to reflect on the ways and extent to which an interest in tropicality facilitates understanding of how this politicisation works. I argue that Césaire's ideas of choc en retour (boomerang effect) and la quotidienneté des barbaries (daily barbarisms) are propitious in this regard. These two ideas invest tropicality's oppositions with an analytics of circulation: they point to how temperate/tropical oppositions are made by practices that connect their opposing parts and expose their hierarchical ordering. More specifically, these ideas help to reveal and challenge the 'temperate north's' dangerous and fateful acquiescence to a politics of comfort and security that bears the footprint of the marketplace, and that tries but fails to disguise its projection of threats and instability on to exotic frontiers. Césaire used the term tropicalité figuratively as well as literally in this respect, to flag how this acquiescence has long hinged on the plunder of tropical lands and resources as well as on a mindset of exception. The upshot of the latter today - its boomerang effect - is the unfurling of intemperance within the 'temperate' West (also see Césaire, 2017).

Malcolm Gladwell (2005) brings this to a harrowing conclusion. While "we assume that biological survival is contingent on the strength of our civilizational values", and with "the lesson taken from the two world wars and the nuclear age...[that] we would survive as a species only if we learned to get along and resolve our disputes peacefully", the fact now looms "that we can be law-abiding and peace-loving and tolerant and inventive and committed to freedom and true to our own values and still behave in ways that are biologically suicidal." Indeed, the consequences of all this chipping away and rot for life on earth may now be beyond human comprehension and humanity's ability to abate. However, such a view can too readily become defeatist and push existence and survival away from what Césaire thought was so crucial: recognition that the human condition is defined by struggle and becomes political through the way struggles are given value and form, and struggles that do not necessarily separate humans from, or pit them against, nature or other humans.

Mbembe (2019, p. 27) has recently extended Césaire's line of thought, arguing that modern democracies operate and survive by concealing the founding violence within them and attributing cruelty and chaos to "third places, to nonplaces, of which the plantation, the colony, or, today, the camp and the prison, are emblematic figures." There is a "primordial and founding void" at the heart of how "democratic order" sees itself, for it establishes and continues to live by "a law that originates in nonlaw". The "mythological logics" by which modern liberal democracies have sought to immunise themselves from contamination and condemnation, and forestalled the need to see 
eTropic 20.1 (2021) Special Issue: Pandemic, Plague, Pestilence and the Tropics

themselves as susceptible to danger and admit that they are generators of it, are "doubled" (at once hidden and propelled), he insists, through the distinction between a "democratic order" and an antithetical "colonial world" where violence and impunity reign.

But the problem today, he continues, is that this 'order' is not immune from this 'world', in some of the same ways in which 'the temperate' is no longer protected from 'the tropical'. While temperate and tropical have not fully imploded as categories, signifiers, or even realities, their coordinates ('the tropics as we knew them') are shifting and might now be deemed moving markers of how 'interiors' and 'exteriors', and 'normalities' and 'abnormalities,' of comfort, distress, exposure, safety, security and vulnerability are imagined and excoriated. Temperate and tropical belong to a more general story about how 'we' face up to issues of blame, responsibility, indemnity, protection, exemption, victimhood, recognition, mutuality and cooperation.

But this is a fluid moment. Will Covid-19 become anything more than just a reminder of Mbembe's (2019, p. 29) doubling, and with the "bare question" of who lives and who dies, which is "latent on the interior" of democracies, once more both answered with abandon on the outside and actualised covertly, and with its own forms of intemperance, on the inside? Or will the global intimacy of Covid-19 and the planetary paralysis presaged by climate change give this dire time, and these questions of immunity and isolation, fewer places to hide, and fewer ways of getting put back into boxes of 'us' and 'them,' 'here' and 'there,' and 'normal' and 'pathological'?

Of course, neither tropicality nor Césaire tell us everything about the choc en retour of Covid-19 and climate change. But they say something. Tropicality, as it is transacted through these intertwined shockwaves, perhaps provides ways of both diagnosing and looking past a time and geography of privilege, isolationism, division and denial, and of seeing and nurturing one of mutual sufferings and shared vigilances. We may well be 'at war' with Covid-19 and climate change (Malm, 2020), but this time also surely calls for love, support, care and respect. 
eTropic 20.1 (2021) Special Issue: Pandemic, Plague, Pestilence and the Tropics

\section{References}

Acemoglu, D. \& Robinson, J. (2019). The narrow corridor: States, societies and the fate of liberty. Penguin.

Agamben, G. (2020). L'invenzione di un'epidemia. Quodlibet 26 February. https://www.quodlibet.it/giorgio-agamben-l-invenzione-di-un-epidemia

Ajana, B. (2021). Immunitarianism: Defence and sacrifice in the politics of Covid-19. HPLS 43 (25) https://doi.org/10.1007/s40656-021-00384-9

Allewaert, M. (2013). Ariel's ecology: Plantations, personhood, and colonialism in the American tropics. University of Minnesota Press. https://doi.org/10.5749/minnesota/9780816677276.001.0001

Arnold, D. (1995). The problem of nature: Environment, culture and European expansion. Basil Blackwell.

Arnold, D. (1998). India's place in the tropical world, 1770-1930. Journal of Imperial and Commonwealth History 26 (1), 1-21. https://doi.org/10.1080/03086539808583013

Arnold, D. (2005). The tropics and the traveling gaze: India, landscape and science, 18001856. Permanent Black.

Asonye, C. (2020). There's nothing new about the 'new normal'. Here's why. World Economic Forum 5 June. https://www.weforum.org/agenda/2020/06/theres-nothingnew-about-this-new-normal-heres-why/

Barbier, E. (2020). Are tropical ecosystems the new frontline against Covid-19? Green Economy Coalition 14 July. https://www.greeneconomycoalition.org/newsanalysis/are-tropical-ecosystems-the-new-frontline-against-covid-19

Belin, C. Bloch, A. \& Nicolaï, J. (2020). France at war against the coronavirus: Politics under anaesthesia? Brookings 31 March. https://www.brookings.edu/blog/order-fromchaos/2020/03/31/france-at-war-against-the-coronavirus-politics-under-anesthesia/

Bhabha, H. (1994). The location of culture. Routledge.

Bloomfield, L. McIntosh, T. \& Lambin, E. (2020). Habitat fragmentation, livelihood behaviors, and contact between people and nonhuman primates in Africa. Landscape Ecology 35, 985-1000. https://doi.org/10.1007/s10980-020-00995-w

Bodkin, H. (2020). Post-Christmas 'tsunami' of Covid hospitalisations expected as ambulance queues double. The Telegraph 18 December.

https://www.telegraph.co.U.K./news/2020/12/18/post-christmas-tsunami-covidhospitalisations-expected-ambulance/

Bowd, G. \& Clayton, D. (2019). Impure and worldly geography: Pierre Gourou and tropicality. Routledge. https://doi.org/10.4324/9781315588087

Bradshaw, C. Ehrlich, P., Beattie, A., Ceballos, G., Crist, E., Diamond, J., Dirzo, R., Ehrlich, A.H., Harte, J., Harte, M.E., Pyke, G., Raven, P.H., Ripple, W.J., Saltré, F., Turnbull, C., Wacker-nagel, M., \& Blumstein, D.T. (2021). Underestimating the challenges of avoiding a ghastly future. Fronters of Conservation Science 13 January. https://doi.org/10.3389/fcosc.2020.615419

British Broadcasting Corporation (BBC) (2021). Juncker: We have to pull back from a Covid vaccine war. 25 March. https://www.bbc.co.uk/news/av/world-europe-56524161

British Medical Association (2020). COVID-19 pandemic has created flood of potentially substandard research. BMJ 1 October.

https://www.bmj.com/company/newsroom/covid-19-pandemic-has-created-flood-ofpotentially-substandard-research/

Césaire, A. (1955). Discours sur le colonialisme. Orig. pub. 1950. Presence Africaine.

Césaire, A. (2000). Discourse on colonialism. (Trans. J. Pinkham; orig. pub. 1972). Monthly Review Press. 
eTropic 20.1 (2021) Special Issue: Pandemic, Plague, Pestilence and the Tropics

Césaire, A. (2017). The complete poetry of Aimé Césaire: Bilingual edition. (Trans. and Eds. A. Arnold \& C. Eshleman). Wesleyan University Press.

Chakrabary, D. (2020). Interview - Toynbee coronavirus series. Toynbee Prize Foundation 17 June. https://toynbeeprize.org/posts/interview-toynbee-coronavirus-series-dipeshchakrabarty-on-the-pandemic-in-the-age-of-the-anthropocene/

Channel 4 News (2020). Have yourselves a merry little Christmas 16 December. https://www.facebook.com/Channel4News/videos/have-yourselves-a-merry-littlechristmas-and-im-afraid-this-year-i-do-mean-littl/1211707449223938/

Chen, J. Huang, W. \& Yao, M. (2020). COVID-19: Impact by and on the Environment Special Issue. Science of the Total Environment 279 https://doi.org/10.1016/j.scitotenv.2020.138862

Chinkin, C. \& Rees, M. (2020). Our male leaders declared war on the pandemic. Our response must match that. LSE Blog 11 May.

https://blogs.Ise.ac.U.K./wps/2020/05/11/our-male-leaders-declared-war-on-thepandemic-our-response-mUSt-match-that/

Churchill Society, The (CS) (1946). Speech. Zurich 19 September. http://www.churchillsociety-london.org.U.K./astonish.html

Clayton, D. (2013). Militant tropicality: war, revolution and the reconfiguration of 'the tropics'c.1940-c.1975. Transactions of the Institute of British Geographers 38 (1), 180-192. https://doi.org/10.1111/j.1475-5661.2012.00510.x

Cole, W. (2020). Leicester's cramped rag trade workshops face 'slavery investigation' after workers supplying fashion giant Boohoo are found to be paid $£ 3.50$ an hour. The Daily Mail 15 June. https://www.dailymail.co.U.K./news/article-8490753/Investigationreveals-Leicester-clothes-workers-supplying-Boohoo-paid-little-3-50-hour.html

Collett, A. McDougall, R. \& Thomas, S. (2017). Tracking the literature of extreme weather: Typhoons, hurricanes, cyclones.Palgrave. https://doi.org/10.1007/978-3-319-41516-1

Connolly, M. \& Heymann, D. (2002). Deadly comrades: War and infectious diseases The Lancet 360, s23-s-24 https://www.thelancet.com/pdfs/journals/lancet/PIIS01406736(02)11807-1.pdf

Conway, E. (2020). Coronavirus: We're all in this together - but some more than others. Sky News - Analysis 4 May. https://news.sky.com/story/coronavirus-were-all-in-thistogether-but-some-more-than-others-11981917

Cosgrove, D. (2005). Tropic and tropicality. In F. Driver \& L. Martins (Eds). Tropical visions in an age of empire (pp. 197-216). University of Chicago Press. https://doi.org/10.7208/chicago/9780226164700.003.0011

Darwell, R. (2017). Green tyranny: Exposing the totalitarian toots of the climate industrial complex. Encounter Books

Defoe, D. (1992). A Journal of the plague year. (Orig. pub. 1772). W.W. Norton.

Delaney, B. (2020). Amid the horror, we look back at this year of the virus with wonder too. The Guardian 30 December.

https://www.theguardian.com/commentisfree/2020/dec/31/amid-the-horror-we-lookback-at-this-year-of-the-virus-with-wonder-too

Delanty, G. (2020). Six political philosophies in search of a virus: Critical perspectives on the coronavirus pandemic. LSE ‘Europe in Question' Discussion Paper Series. https://www.Ise.ac.uk/european-institute/Assets/Documents/LEQS-DiscussionPapers/LEQSPaper156.pdf

Derrida, J. (1977). Limited Inc. (Trans. S. Weber). Northwestern University Press.

Devakumar, D., Shannon, G., Bhopal, S. \& Abubakar, I. (2020). Racism and discrimination in COVID-19 responses. The Lancet 395, 1 April. https://doi.org/10.1016/S01406736(20)30792-3 
eTropic 20.1 (2021) Special Issue: Pandemic, Plague, Pestilence and the Tropics

Dinh, T. (2020). What the coronavirus and the Vietnam War share. NBC News - THINK 29 November. https://www.nbcnews.com/think/opinion/what-coronavirus-vietnam-warshare-homeschooling-distancing-fearing-your-life-ncna1217776

Donner, S. (2020). The ugly history of climate determinism is still evident today Scientific American 24 June. https://www.scientificamerican.com/article/the-ugly-history-ofclimate-determinism-is-still-evident-todayl

Dorling, D. (2020). Want to understand the Covid map? Look at where we live and how we work. The Guardian 29 November.

https://www.theguardian.com/commentisfree/2020/nov/29/want-to-understand-thecovid-map-look-at-where-we-live-and-how-we-work

Driver, F. (2004). Imagining the tropics: Views and visions of the tropical world," Singapore Journal of Tropical Geography 25 (1), 1-17. https://doi.org/10.1111/j.01297619.2004.00167.x

Drum, K. (2020). Who invented the phrase 'social distancing'? Mother Jones 26 April. https://www.motherjones.com/kevin-drum/2020/04/who-invented-the-phrase-socialdistancing/

Edgerton, D. (2021). The one good thing to come out of Brexit: a bonfire of national illusions. The Guardian 1 January. https://www.theguardian.com/commentisfree/2021/jan/01/brexit-bonfire-nationalillUSions-labour-alternative-future

Elgot, J. (2021). 'No. 10 was a plague pit': How Covid brought Westminster to its knees. The Guardian 12 March. https://www.theguardian.com/politics/2021/mar/12/no-10-plaguepit-how-covid-brought-westminster-to-its-knees

Endfield, G. (2019). Weather and elemental places. Distinguished Lecture - 2019 Historical Geography 47 (1), 1-31. https://doi.org/10.1353/hgo.2019.0023

Euronews (2020). We're going to have to learn to live with virus. Euronews 9 November. https://www.euronews.com/2020/09/11/we-re-going-to-have-to-learn-to-live-withvirus-says-eu-health-boss

Foss, K. (2020). Constructing the outbreak: Epidemics in media and collective memory. Massachusetts University Press. https://doi.org/10.2307/j.ctv1d37dwr

Foucault, M. (1977). Discipline and punish: The birth of the prison. (Trans. A. Sheridan). Allen Lane.

Foucault, M. (1978). The history of sexuality, vol 1. (Trans. R Hurley). Random House.

Gladwell, M. (2005). The vanishing. The New Yorker 3 January. https://www.newyorker.com/magazine/2005/01/03/the-vanishing-2

Gourou, P. (1963). Le déterminisme physique dans 'I'Esprit des lois.' L'Homme 3 (3), 5-11. https://doi.org/10.3406/hom.1963.366577

Greene, A. (2020). State of emergency: How different countries are invoking extra powers to stop the coronavirus. The Conversation 30 March. https://theconversation.com/stateof-emergency-how-different-countries-are-invoking-extra-powers-to-stop-thecoronavirus- 134495

Hagen, A. Strahan-Sakoskie, D. \& Luckett, C. (2012). A reanalysis of the 1944-53 Atlantic hurricane seasons - the first decade of aircraft reconnaissance. Journal of Climate 25 (13), 4441-4460. https://doi.org/10.1175/JCLI-D-11-00419.1

Hall T. \& Ross D. (2020). Can the U.K. win back its collective memory of epidemics? BMJ Military Health 30 September. http://dx.doi.org/10.1136/bmimilitary-2020-001634

Hall, S. (1996). When was the postcolonial? Thinking at the limit. In I. Chambers \& L. Curti (Eds). The postcolonial question: Common skies, divided horizons (pp. 242-260). Routledge.

Hasan, N. \& Haque, M. (2020). Predict the next moves of COVID-19: Reveal the temperate and tropical countries scenario. medRxiv 4 April.

https://doi.org/10.1101/2020.04.04.20052928 
eTropic 20.1 (2021) Special Issue: Pandemic, Plague, Pestilence and the Tropics

Henley, J. (2020). World's media ask how it went so wrong for 'Plague Island' Britain The Guardian 22 December. https://www.theguardian.com/world/2020/dec/22/worldsmedia-ask-how-it-went-so-wrong-for-plague-island-britain-covid

Howell, B. (2021). The countries who've handled coronavirus the best - and worst. MoveHub 2 March. https://www.movehub.com/blog/best-and-worst-covidresponses/\#two

Hulme, M. (2008). The conquering of climate: Discourses of fear and their dissolution. The Geographical Journal 174 (1), 5-16. https://doi.org/10.1111/j.14754959.2008.00266.x

Institute for Global Change (2020). Insights from Africa's Covid-19 response. 17 December. https://institute.global/advisory/insights-africas-covid-19-response

Jericho, G. (2005). War in the tropics. eTropic: electronic journal of studies in the tropics 4 https://doi.org/10.25120/etropic.4.0.2005.3439

Jones, E. (2020). The psychology of protecting the UK public against external threat: COVID-19 and the Blitz compared. The Lancet 7 (11), 991-996. https://www.thelancet.com/journals/lanpsy/article/PIIS2215-0366(20)30342-4/fulltext

Kumar, A. (2020). Monopsony capitalism. Power and production in the twilight of the sweatshop age. Cambridge University Press. https://doi.org/10.1017/9781108764810

Laino, C. (2003). Africa, the infectious continent NBC News Blog https://www.nbcnews.com/id/wbna3072106

Lee, D. (2020). Covid's 'viral tsunami' floods California's hospitals. Financial Times 25 December. https://www.ft.com/content/3c46f6d5-c9b3-451a-a418-17336e9160e5

Livingstone, D. (2012). Reflections on the cultural spaces of climate. Climatic Change 113, 91-93. https://doi.org/10.1007/s10584-012-0409-5

Liu, A. (2020). 'Chinese virus,' world market. N+1 20 March. https://nplUSonemag.com/online-only/online-only/chinese-virus-world-market/

Mabille, P. (1978). La jungle. (Orig. pub. 1945). In A. Césaire \& S. Roussi (Eds). Tropiques II (pp. 185-189). Jean-Michel Place.

MacDonald, G. (2020). Climate, capital, conflict: Geographies of success or failure in the twenty-first century. Annals of the American Association of Geographers 110 (6), 2011-2031. https://doi.org/10.1080/24694452.2020.1800300

Mahoney, M. (2016). Picturing the future-conditional: Montage and the global geographies of climate change. Geo: Geography and Environment 3 (2), 1-18. https://doi.org/10.1002/geo2.19

Mahoney, M. \& Endfield, G. (2018). Climate and colonialism. WIREs: Climate Change 9, 116. https://doi.org/10.1002/wcc.510

Mahoney, M. \& Hulme, M. (2018). Epistemic geographies of climate change: Science, space and politics. Progress in Human Geography 42 (3), 395-424. https://doi.org/10.1177/0309132516681485

Malm, A. (2020). Corona, climate, chronic emergency: War communism in the twenty-first century. Verso.

Mason, R. (2020). Coronavirus: London hospitals facing 'tsunami' of patients. The Guardian 26 March. https://www.theguardian.com/world/2020/mar/26/london-hospitals-facingtsunami-of-coronavirus-patients-overwhelmed

Mbembe, A. (2019). Necropolitics. Duke University Press. https://doi.org/10.1515/9781478007227

Mbembe, A. (2020a). The universal right to breathe. Critical Inquiry (Trans. C. Shread) 13 April. https://critinq.wordpress.com/2020/04/13/the-universal-right-to-breathe/ 
eTropic 20.1 (2021) Special Issue: Pandemic, Plague, Pestilence and the Tropics

Mbembe, A. (2020b). The pandemic democratizes the power to kill. An interview with Diogo Bercito. European Journal of Psychoanalysis 31 March. https://www.journalpsychoanalysis.eu/the-pandemic-democratizes-the-power-to-kill-an-intyerview/

McCarthy, M. (2021). Met Office: A review of the U.K.'s climate in 2020. Carbon Brief 12 January. https://www.carbonbrief.org/met-office-a-review-of-the-U.K.s-climate-in2020

McGrath, M. (2018). Weather: U.K. experiencing hotter days and 'tropical nights' - Met Office. BBC News - Science-Environment 2 March. https://www.bbc.co.U.K./news/science-environment-46064266

McKie, R. (2021). Neil Ferguson: 'One year ago, I first realised how serious coronavirus was. Then it got worse...' The Guardian 14 March. https://www.theguardian.com/world/2021/mar/14/neil-ferguson-one-year-ago-i-firstrealised-how-serious-coronavirus-was-then-it-got-worse-covid

McNeill, W. (1976). Plagues and peoples. Doubleday.

Mellish, T. Luzmore, N. \& Shahbaz A. (2020). Why were the U.K. and U.S.A. unprepared for the COVID-19 pandemic? The systemic weaknesses of neoliberalism: a comparison between the U.K., USA, Germany, and South Korea. Journal of Global Faultlines 7 (1), 9-45. https://doi.org/10.13169/jglobfaul.7.1.0009

Meyers, W. \& Guss, D. (2017). Neo-environmental determinism. Palgrave. https://doi.org/10.1007/978-3-319-54232-4

Mirror (2020). Furious truckers trapped in Dover 'without toilets' being treated like 'animals' 23 Dec. https://www.mirror.co.U.K./news/U.K.-news/furioUS-truckers-trapped-doverwithout-23211637

Morti, S. (2015). Mangoes and monsoons: South Asia media coverage of environmental spectacles. In J. Leyda \& D. Negra (Eds.) Extreme weather and global media. (pp. 163-190). Routledge. https://doi.org/10.4324/9781315756486-8

Mouamfon, M. \& Tagne, C. (2020). How is COVID-19 affecting wild meat consumption in rural Cameroon? International Institute for Environment and Development 2 November. https://www.iied.org/how-covid-19-affecting-wild-meat-consumption-ruralcameroon

Nancy, J-L. (2020). Viral exception. 27 April. In On Pandemics. Nancy, Dwivedi, Mohan, Esposito, Nancy, Ronchi The European Journal of Psychoanalysis https://www.journal-psychoanalysis.eu/on-pandemics-nancy-esposito-nancy/.

Naraindas, H. (1996). Poisons, putrescence and the weather: A genealogy of the advent of tropical medicine. Contributions to Indian Sociology 30 (1), 31-55. https://doi.org/10.1177/006996679603000101

Nguyen, T.V., Tran, Q.D., Phan, L.T., Vu, L.N., Truong, D.T.T., Truong, H.C., Le, T.N., Vien, L.D.K., Nguyen, T.V., Luong, Q.C., Pham, Q.D. (2021). In the interest of public safety: rapid response to the COVID-19 epidemic in Vietnam. BMJ Global Health 6 (1), e004100 https://doi.org/10.1136/bmjgh-2020-004100

Ntoumi, F. (2020). Tropical diseases need attention too. Nature - World View 17 November. https://www.nature.com/articles/d41586-020-03220-5

Opillard, F. Palle, A. \& Michelis, L. (2020). Discourse and strategic use of the military in France and Europe in the Covid-19 crisis. Tijdschrift voor Economische en Sociale Geografie 111 (3), 239-259. https://doi.org/10.1111/tesg.12451

Ortiz, F. ([1940] 1971). Cuban counterpoint: Tobacco and sugar. Duke University Press.

Otte, J. (2021). NHS could vaccinate U.K. against Covid in five days, says Oxford professor. The Guardian 9 January. https://www.theguardian.com/world/2021/jan/09/nhsvaccinate-U.K.-covid-five-days-oxford-professor

Parenti, C. (2011). Tropic of chaos: Climate change and the new geography of violence. Verso. 
eTropic 20.1 (2021) Special Issue: Pandemic, Plague, Pestilence and the Tropics

Peters, M. (2020). Žižek on China and COVID-19: Wuhan, authoritarian capitalism, and empathetic socialism in NZ. Educational Philosophy and Theory https://doi.org/10.1080/00131857.2020.1801122

Poole, S. (2020). 'Frontline': Is it misleading to apply military metaphors to medicine? The Guardian 16 April. https://www.theguardian.com/books/2020/apr/16/frontline-is-itmisleading-to-apply-military-metaphors-to-medicine

Public Health England (PHE), U.K. Government (2021). PHE statement on Variant of Concern and new Variant Under Investigation. 10 February. https://www.gov.U.K./government/news/phe-statement-on-variant-of-concern-andnew-variant-under-investigation

Public Health England (PHE), U.K. Government (2020). Data series on deaths in people with COVID-19. 12 April.

https://assets.publishing.service.gov.U.K./government/uploads/system/uploads/attac hment data/file/916035/RA Technical Summary PHE Data Series COVID 19 Deaths 20200812.pdf

Rainforest Alliance (2020). Global COVID-19 report. 30 June. https://www.rainforestalliance.org/articles/global-covid-19-report

Ratcliffe, R. (2021). Tate \& Lyle accused of betraying Cambodian families whose land was allegedly taken. The Guardian 2 January. https://www.theguardian.com/bUSiness/2021/jan/02/tate-lyle-accUSed-of-betrayingcambodia-families-whose-land-was-allegedly-taken

Redaelli, S. (2020). Covid-19 and the perception of freedom. openDemocracy 4 August. https://www.opendemocracy.net/en/can-europe-make-it/covid-19-and-perceptionfreedom/

Reuters (2021). Natural Disasters - Headlines. 4 January. https://www.reuters.com/news/archive/tsunami

Ross, C. (2017). Ecology and power in the age of empire: Europe and the transformation of the tropical world. Oxford University Press. https://doi.org/10.1093/acprof:oso/9780199590414.001.0001

Sachs, J. (2001). Tropical underdevelopment. NBER Working Article No. 8119. https://doi.org/10.3386/w8119

Sachs, J. (2018). We are all climate refugees now" Project Syndicate 2 August. https://www.project-syndicate.org/commentary/climate-change-disaster-in-themaking-by-jeffrey-d-sachs-2018-08

Said, E. (1978). Orientalism. Random House.

Saunders, R. (2019). Myths from a small island: The dangers of a buccaneering view of British history. New Statesman 10. https://www.newstatesman.com/politics/U.K./2019/10/myths-small-island-dangersbuccaneering-view-british-history

Schultz, J.M., Kossin J.P., Aleeza, A., Borowy, V., Fugate, C., Espinel, Z., Galea, S. (2020). Superimposed threats to population health from tropical cyclones in the pre-vaccine era of COVID-19. Lancet: Planetary Health 4 (11), 506-508. https://doi.org/10.1016/S2542-5196(20)30250-3

Shariatmadari, D. (2020). 'Invisible mugger': How Boris Johnson's language hints at his thinking. The Guardian 27 April. https://www.theguardian.com/politics/2020/apr/27/muggers-and-invisible-enemieshow-boris-johnsons-metaphors-reveals-his-thinking

Sliiip (2020). Covid-19 and healthcare's guerrilla warfare. https://sliiip.com/covid-19-andhealthcares-guerrilla-warfare/

Snowden, F. (2019). Epidemics and society: From the Black Death to the present. Yale University Press. https://doi.org/10.2307/j.ctvqc6gg5 
eTropic 20.1 (2021) Special Issue: Pandemic, Plague, Pestilence and the Tropics

Spicer, C. (2016). 'The cyclone which is at the heart of things': The cyclone as trope of place and apocalypse in Queensland literature. eTropic: electronic journal of studies in the tropics, 15 (2), 58-68. https://doi.org/10.25120/etropic.15.2.2016.3542

Stam, R. (1997). Tropical multiculturalism: A comparative history of race in Brazilian cinema and culture. Duke University Press.

Staten, P.W., Lu, J., Grise, K.M., Davis, S.M., \& Birner, T. (2018). Re-examining tropical expansion. Nature - Climate Change 8, 768-775. https://doi.org/10.1038/s41558018-0246-2

Stepan, N. (2001). Picturing tropical nature. Reaktion Books.

Sutter, P. (2014). The tropics: A brief history of an environmental imaginary. In A. Isenberg (Ed). The Oxford handbook of environment history (pp. 178-198). Oxford University Press.

Swatuk, L. Thomas, B. Wirkus, L. Krampe, F. \& Batista da Silva, L. (2020). The 'boomerang effect': Insights for improved climate action. Climate and Development. https://doi.org/10.1080/17565529.2020.1723470

Syal, R. (2021). No evidence £22bn test-and-trace scheme cut Covid rates in England, say MPs. The Guardian 10 March. https://www.theguardian.com/world/2021/mar/10/noevidence-22bn-test-and-trace-scheme-cut-covid-rates-in-england-say-mps

The Daily Mail (2012). The tropics are moving northwards. 16 May. https://www.dailymail.co.U.K./sciencetech/article-2145120/The-tropics-movingnorthwards-thanks-ozone--bad-news-Britain-means-MORE-rain-US.html

Tilley, H. (2016). Medicine, empires and ethics in colonial Africa. AMA Journal of Ethics 18 (7), 743-753. https://doi.org/10.1001/journalofethics.2016.18.7.mhst1-1607

Trase (2018). Trase yearbook: 2018. https://yearbook2018.trase.earth/

Tushabe, F. (2020). Comparison of COVID-19 severity between tropical and non-tropical countries. International Journal of Infection 7 (3), e104142. https://doi.org/10.5812/iji.104142

U.K. Climate Change Committee - Adaptation Sub-Committee (2010). How well prepared is the U.K. for climate change? https://www.theccc.org.U.K./wpcontent/uploads/2010/09/CCC ASC Report ES web 1.pdf

U.K. Government (2020a). National lockdown: Stay at home. 23 March. https://www.gov.U.K./guidance/national-lockdown-stay-at-home

U.K. Government (2020b). Press release: Health Secretary sets out government 'battle plan' for COVID-19. 1 March. https://www.gov.U.K./government/news/health-secretarysets-out-government-battle-plan-for-covid-19

U.K. Met Office (2018). Extreme weather reveals changing climate. Press release 1 November. https://www.metoffice.gov.U.K./about-US/pressoffice/news/corporate/2018/climate-extremes-report-supplement

Viboud, C., Tam, T., Fleming, D., Miller, M. A., \& Simonsen, L. (2006). 1951 influenza epidemic, England and Wales, Canada, and the United States. Emerging Infectious Diseases 12 (4), 661-668. https://doi.org/10.3201/eid1204.050695

Vidal, J. (2020). 'Tip of the iceberg': Is our destruction of nature responsible for Covid-19? The Guardian 18 March. https://www.theguardian.com/environment/2020/mar/18/tipof-the-iceberg-is-our-destruction-of-nature-responsible-for-covid-19-aoe

Voskoboynik, D. (2018). 'To fix the climate crisis, we must face up to our imperial past.' openDemocracy 8 October.

https://www.opendemocracy.net/en/opendemocracyU.K./to-fix-climate-crisis-wemUSt-acknowledge-our-imperial-past/

Wilder, G. (2015). Freedom time: Negritude, decolonization, and the future of the world. Duke University Press. https://doi.org/10.1515/9780822375791

Winning, A. (2020). Puzzled scientists seek reasons behind Africa's low fatality rates from pandemic. Reuters-Health 29 September. https://www.reuters.com/article/U.K.- 
eTropic 20.1 (2021) Special Issue: Pandemic, Plague, Pestilence and the Tropics

health-coronavirus-africa-mortality-i/puzzled-scientists-seek-reasons-behind-africaslow-fatality-rates-from-pandemic-idINKBN26KOAK

Winter, J. (1995). Sites of memory, sites of mourning: The Great War in European cultural history. Cambridge University Press.

World Health Organization (2020). From the 'new normal' to a 'new future': A sustainable response to COVID-19. 13 October.

https://www.who.int/westernpacific/news/commentaries/detail-hq/from-the-newnormal-to-a-new-future-a-sUStainable-response-to-covid-19

York, C. (2020). Boris Johnson uses series of bizarre war metaphors in defence of new coronavirus restrictions. Huffington Post 27 November.

https://www.huffingtonpost.co.U.K./entry/boris-johnson-coronavirusrules U.K. 5fc38bd7c5b66bb88c67af7a?

Ypi, L. (2019). Johnson's defence of war metaphors and blame of all sides turns MPs into enemy targets. LSE BPP 4 October. https://blogs.Ise.ac.U.K./politicsandpolicy/warmetaphors-johnson/

Zhou, J. (2016). Boomerangs versus javelins: How polarization constrains communication on climate change. Environmental Politics 25 (5), 788-811.

https://doi.org/10.1515/9780822375791

Dr Dan Clayton is Senior Lecturer and Director of Research in the School of Geography and Sustainable Development, University of St Andrews, Scotland, and co-editor of The Scottish Geographical Journal. He has written widely on questions of tropicality, empire, and decolonisation, and was working on a project entitled 'the jungle environment of the Vietnam War' when Covid-19 hit and everything got shut down. He is author and editor, recently, of Impure and Worldly Geography: Pierre Gourou and Tropicality (2019, with G. Bowd), and journal special issues on 'COP26 and the Crucible of Crisis,' 'Geography and Decolonisation,' 'European Geographers and World War II,' and 'British and French Tropicality'. dwc3@standrews.ac.U.K. 